\title{
Research Paper \\ Comparison of the Effect of Mindfulness-Based Cognitive Therapy (MBCT) and Progressive Muscle Relaxation (PMR) on General Health Indicators in the Mothers of Children with Leukemia
}

\author{
Shiva Manzomeh ${ }^{1}$, Bahman Akbari ${ }^{* 2}$ \\ 1. Ph.D. Student of Psychology, Rasht Branch. Islamic Azad University, Rasht, Iran \\ 2. Associate Professor, Department of Psychology, Rasht Branch, Islamic Azad University, Rasht, Iran
}

Citation: Akbari B, Manzomeh S. Comparison of the effect of mindfulness-based cognitive therapy (MBCT) and progressive muscle relaxation (PMR) on general health indicators in the mothers of children with leukemia. Quarterly Journal of Child Mental Health. 2019; 6(2): 13-26.

http://dx.doi.org/10.29252/jcmh.6.2.3

\section{A R T I C L E I N F O}

Keywords:

Mindfulness-based cognitive-behavioral therapy (MBCT), progressive muscle relaxation (PMR), general health, leukemia

Received: 16 Jun 2018

Accepted: 23 Jan 2019

Available: 10 Aug 2019

\section{A B S T R A C T}

Background and Purpose: The diagnosis of cancer in children causes a lot of anxiety and distress among their parents. Therefore, besides treating the children with cancer, it is essential to use efficient interventional techniques to enhance the mental health of their parents. The present study was conducted to compare the effect of Mindfulness-based Cognitive Therapy (MBCT) and Progressive Muscle Relaxation (PMR) on the general mental health indicators in the mothers of children with leukemia.

Method: The present study was a quasi-experimental research with pretest-posttest control group design. The sample consisted of 45 mothers of the children with cancer who had referred to the oncology ward of 17 Shahrivar hospital of Rasht in 2017. They were selected by convenience sampling and then assigned randomly into three groups of mindfulness therapy $(n=15)$, relaxation training $(n=15)$ and control group $(n=15)$. Demographic questionnaire, interview, cancer diagnostic tests, and general health questionnaire were the instruments used in this research study. After the pretest, the two experimental groups received the interventions for two months $(8$ sessions of two hours), whereas the control group received no intervention. Then, all three groups were evaluated at the stages of posttest and follow up.

Results: Data analysis by repeated measures ANOVA showed significant differences between the groups in physical complaints $(\mathrm{F}=6.622, \mathrm{P}<0.01)$, anxiety $(\mathrm{F}=10.236, \mathrm{P}<0.01)$, social dysfunction $(\mathrm{F}=4.452, \mathrm{P}<0.05)$ and depression $(\mathrm{F}=10.866, \mathrm{P}<0.01)$. The difference between the stages of pretest, post-test, and follow-up was significant in anxiety $(\mathrm{F}=46.681, \mathrm{P}<0.01)$, social dysfunction $(\mathrm{F}=12.610, \mathrm{P}<0.05)$ and depression $(\mathrm{F}=3.870, \mathrm{P}<0.05)$, but no significant difference was observed in physical complains $(\mathrm{F}=1.720, \mathrm{P}>0.05)$.

Conclusions: Results showed that there was no significant difference between MBCT and PMR in improving the general health indicators in mothers of children with leukemia; however, both methods were effective in improving the mental health of mothers. Mindfulness improves the mental health indicators in individuals through training the attention control and time management. Also, the relaxation caused plays a role in decreasing the stress, anxiety, and depression of individuals. Consequently, both methods can be used together to improve the general health of parents of children with cancer.

\footnotetext{
* Corresponding author: Bahman Akbari, Associate Professor, Department of Psychology, Rasht Branch, Islamic Azad University, Rasht, Iran. E-mail addresses: Bakbari44@@gmail.com
} 


\section{مقايسه تأثير شناختدرمانى مبتنى بر ذهن آكاهى و تنشزدايى بيشرونده عضلانى بر شاخصهاى

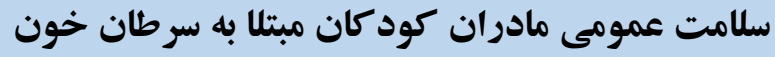

\section{شيوا منظومه '، بهمن اكبرى}

ا. ا. دانشوى دكتراى روانشناسى، واحد رشت، دانشكاه آزاد اسلامى، رشت، ايران

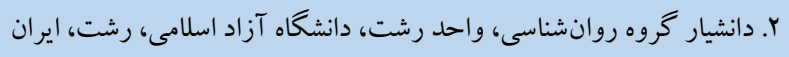

زمينه و هدف: اطلاع از تشخيص سرطان كودك براى والدين بسيار نخران كننده و اضطرابآور است، بنابر اين در كنار درمان فرزند مبتلا به

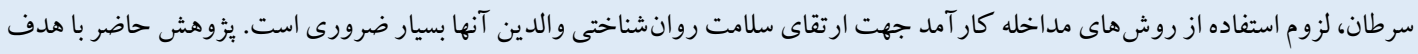

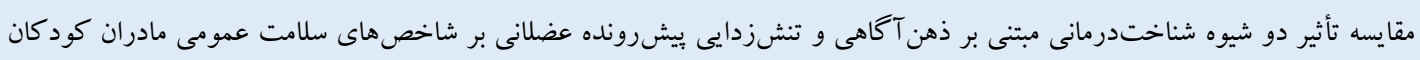
مبتلابه سرطان خون، انجام شد. روش: روش يثزوهش حاضر نيمه آزمايشى و طرح يزوهش از نوع بيش آزمون-يس آزمون با گروه گواه بود. نمونه مورد مطالعه شامل هان نفر

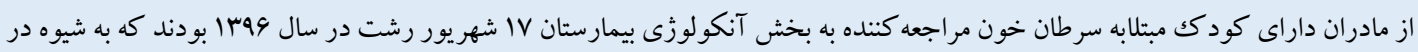

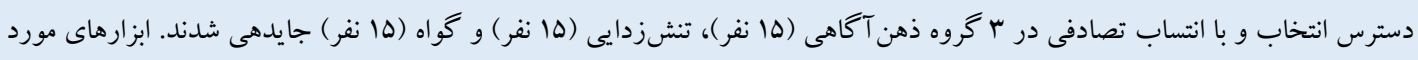

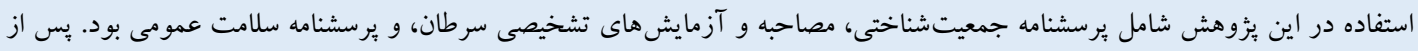

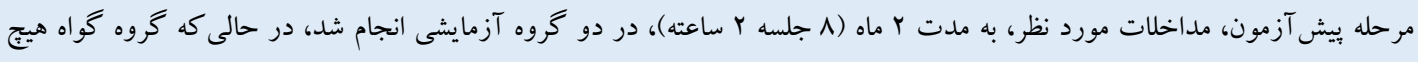

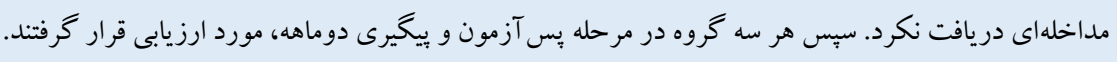

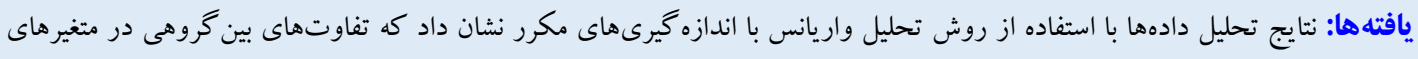

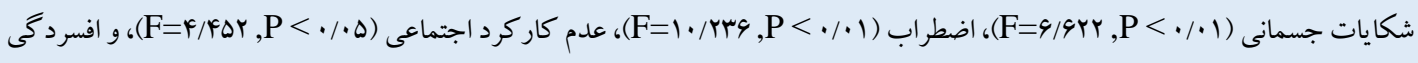

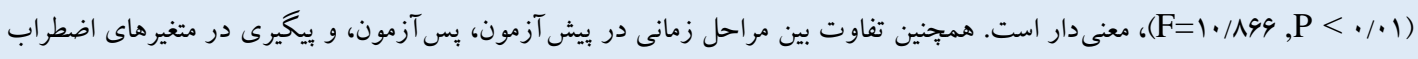

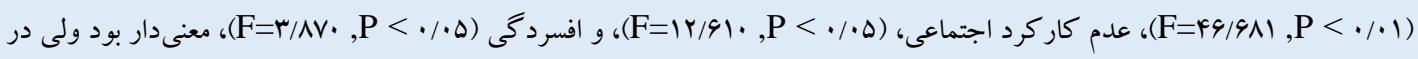

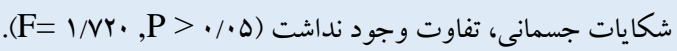

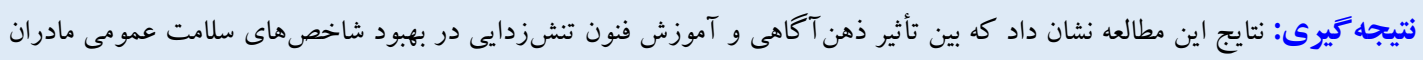
كود كان مبتلا به سرطان خون، تفاوت معنادارى وجود ندارد ولى هر دو شيوه در بهبود وضعيت روانى مادران مؤثر هستند. ذهن آكاهى از طريق

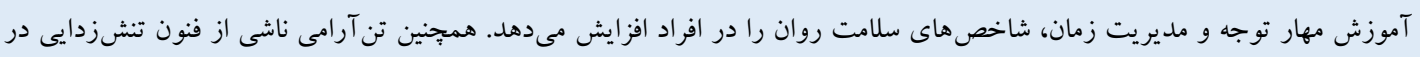

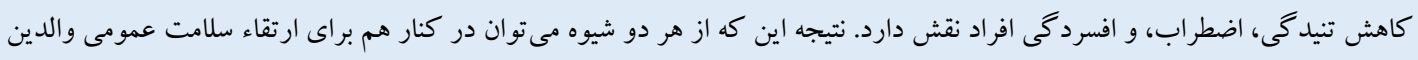

كود كان مبتلا به انواع سرطان، استفاده كرد.
كليدوازهها: شناخت درمانى مبتنى بر ذهن آكاهى، تنش زدايى بيشرونده عضلانى،

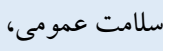

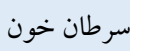
دريافت شده:

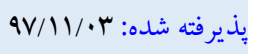

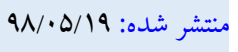

* نويسنده مسئول: بهمن اكبرى، دانشيار گروه روانشناسى، واحد رشت، دانشكاه آزاد اسلامى، رشت، ايران.

رايانامه: Bakbari44@ gmail.com

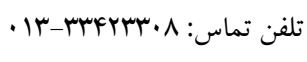


و اجتماعى و حل تضـادها و تمايلات شـخصسى بهطور منطقى، عادلانه و مناسب تعريف مى كند (V). بر اساس اين توصيفات بايد توجه داشت كه كهاس

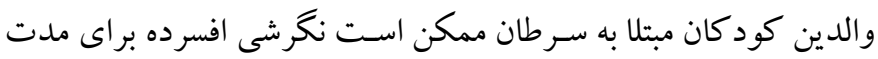

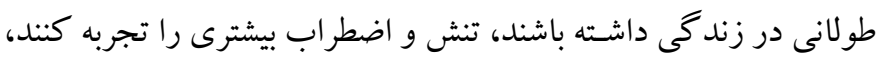

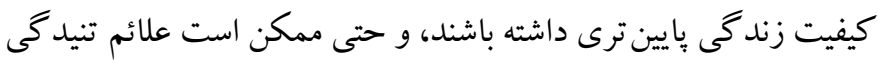

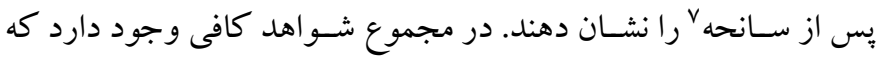

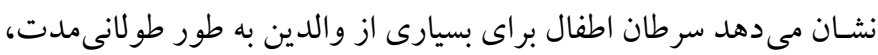

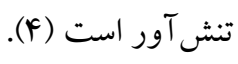

برنـامسهــا و مـداخلـههـاى درمـانى مختلفى را مى توان جهت كاهش تنشها و مشكلات عاطفى و روانشناختى والدين داراى كود كان مبتلا به

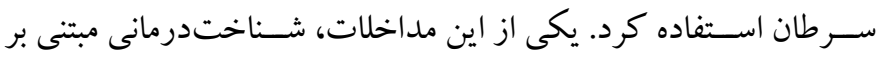
ذهن آكاهى ^اسـت. ذهن آكاهى به حالت يردازش مهارشــه، هشيارانه و

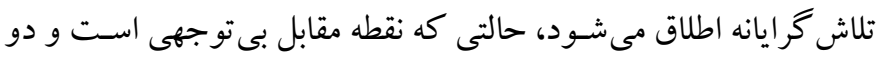

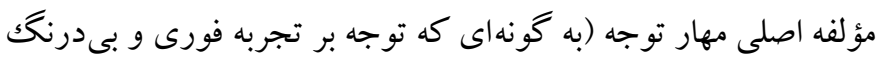
متمر كز شود و درنتيجه امكان بازشناسى رويدادهاى ذهنى جارى افزايش

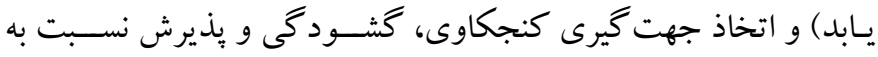

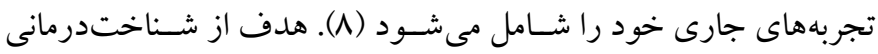

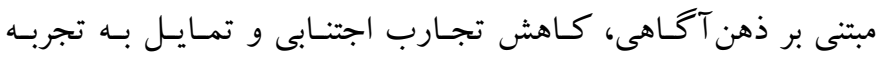

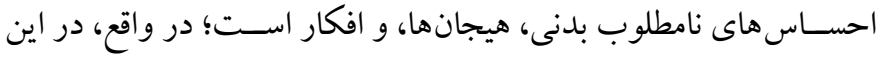

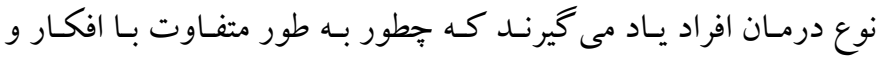
احسـاسـات منفى خود ارتباط برقرار كنند و بر آنها غلبه كنند. همجنين

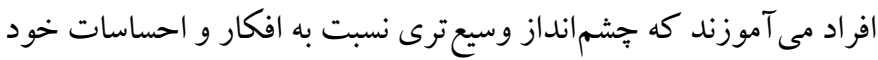

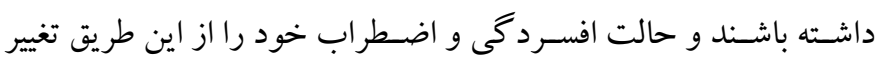

دهند (9).

شـمارى از ئزوهش ها اثربخشى شناخت درمانى مبتنى بر ذهن آكاهى

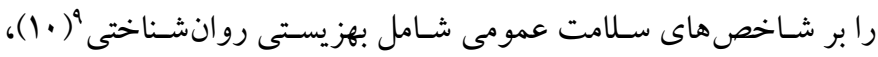

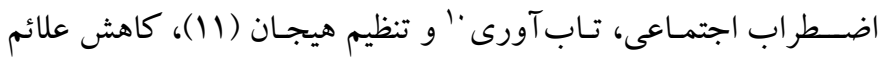

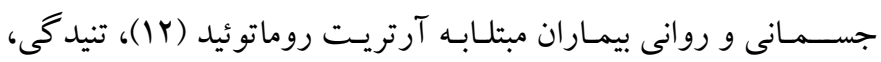

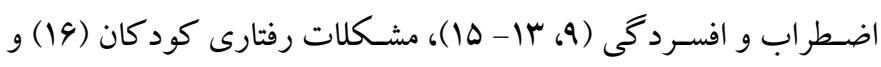

6. World Health Organization

7. Symptoms of ost-Traumatic Stress

8. Mindfulness-Based Cognitive Therapy (MBCT)

9. Psychological Well-Being

10. Resiliency
مقلدمه

سرطان' يكى از معضــلات مهم بهداشـتى و سـومين عامل مر گكومير در

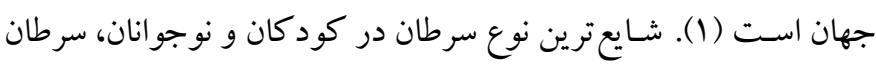

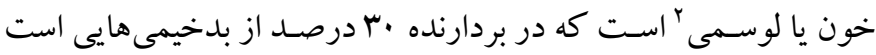

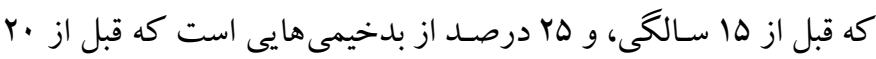

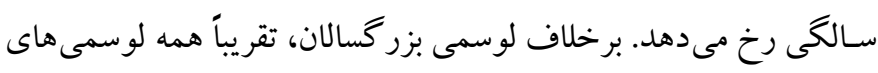

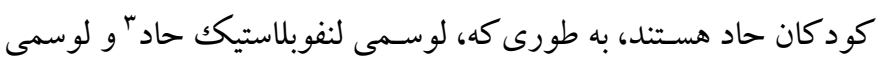

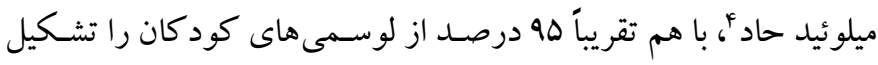

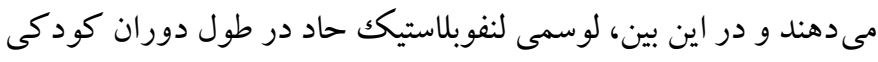

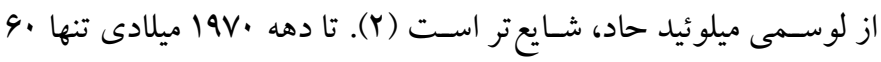

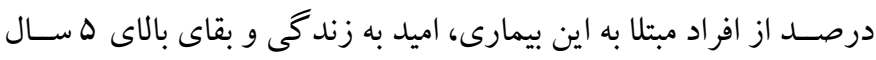

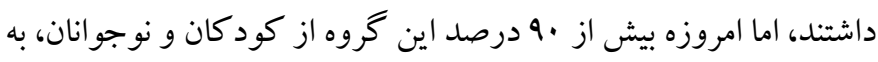

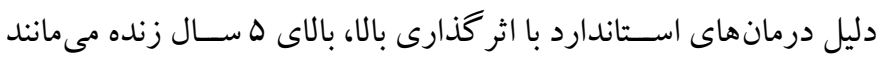

تجربه سـرطان در كودكى، يك عامل تنش آور مهيب براى كود كان

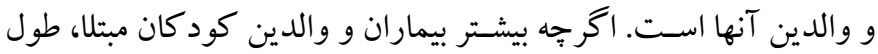

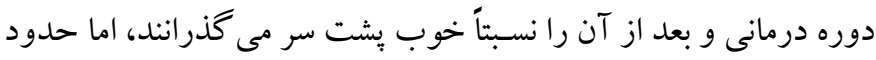

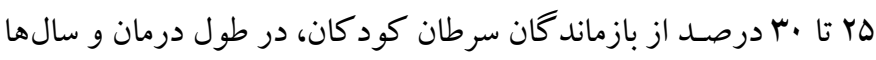

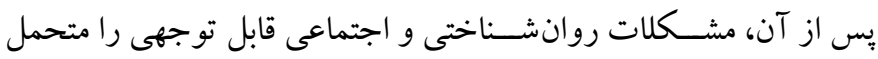

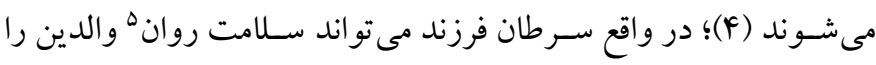

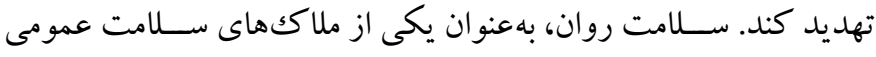

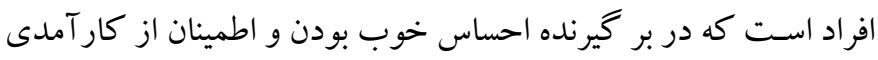
خود، اتكاء به خود، ظرفيت رقابت، تعلق بين نسلى و خودشكوفايى بالقوه

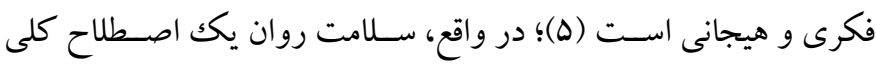
است و به صورت رفاه كامل جسمى، روانى و اجتماعى تعريف مى شود،

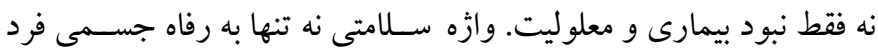

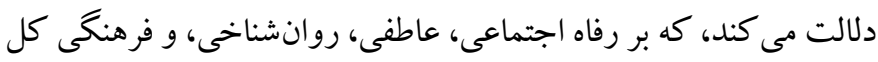

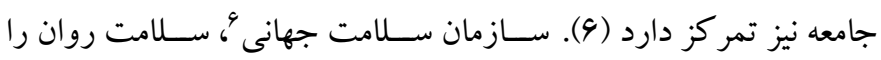
قابليت ارتباط موزون و هماهنگك با ديخران، تغيير و اصسلاح محيط فردى درد

1. Cancer

2. Leukemia

3. Acute Lymphoblastic Leukemia (ALL)

4. Acute Myeloid Leukemia (AML)

5. Mental Health 
واكنش يذيرى ايجاد شـــه در خلق از طريق شـيوه درمانى ذهن آكاهى،

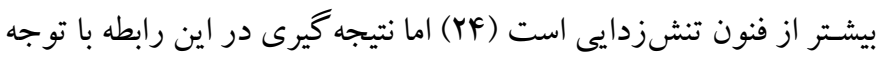
به محدود بودن مطالعات مقايسهاى، بسيار دشوار است.

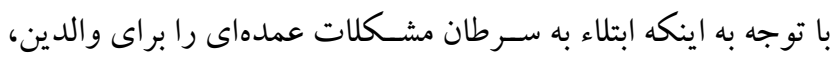

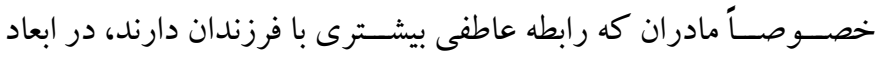

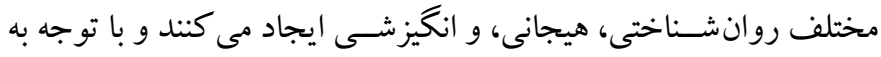

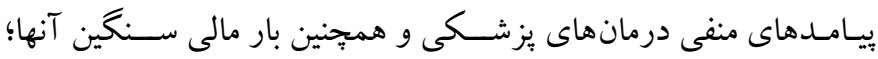

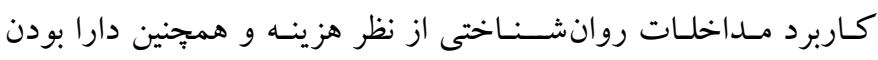

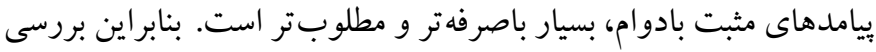

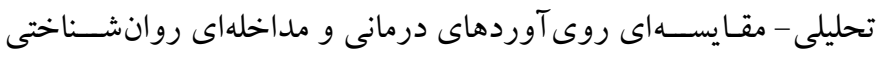

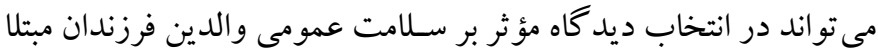

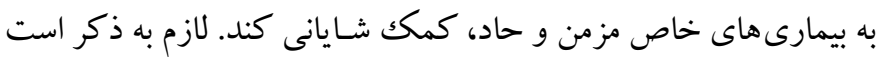

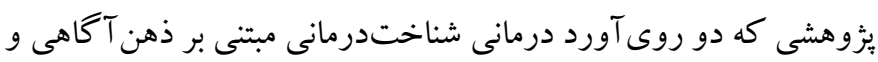
تنشزدايى بيشرونده عضلانى را در بهبود وضعيت روانشناختى مادران كود كان مبتلا به سـرطان خون به صسورت تحليلى مقايسـهاى، بسـنجد در ايران وجود ندارد و در سـاير كشـورها نيز به صـورت محدود انجام شده

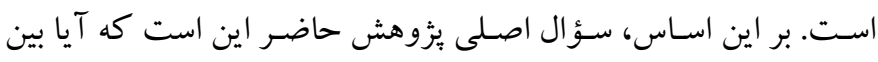

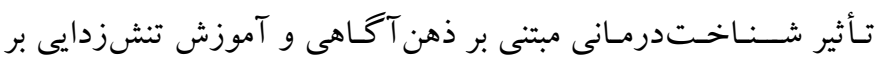

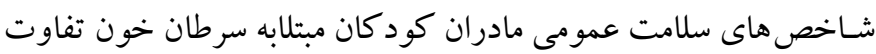

$$
\text { معنادارى وجود دارد؟ }
$$

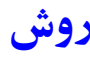

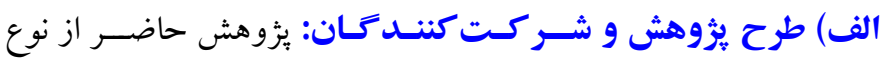

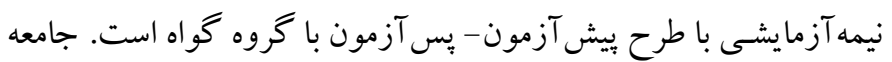
آمارى اين مطالعه شامل تمامى مادران داراى كودك مبتلا به سرطان خون بود كه به بخش آنكولوزى مركز آموزشى و درمانى VI شهريور كود كان

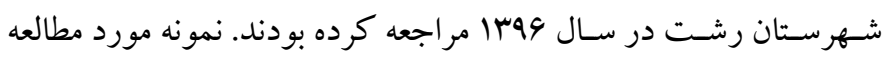

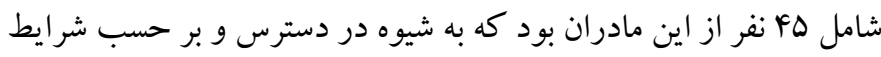

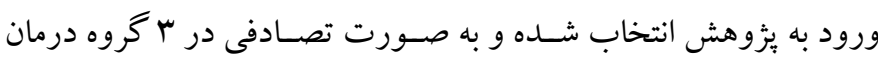

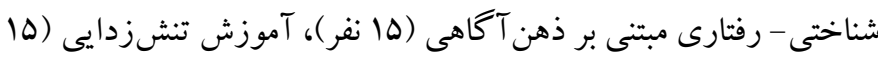

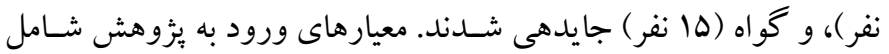

همجنين بر سـلامت روان (9، IV -19)، نشـان دادهاند. شـواهد يُزوهشى حاكى از آن اسـت كه درمان ذهن آكاهى مبتنى بر شــناخت به واســه

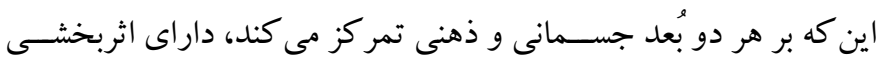

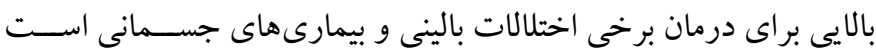

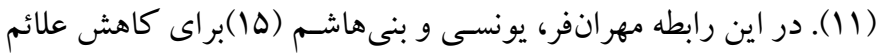

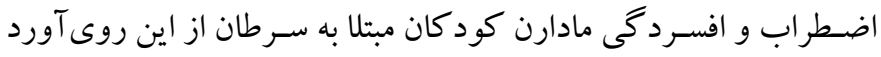

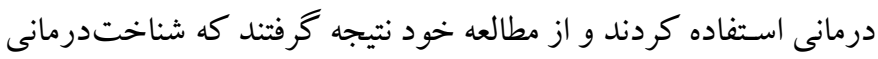

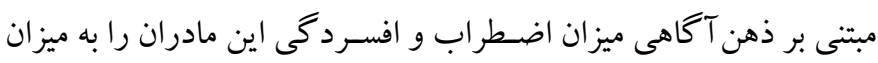

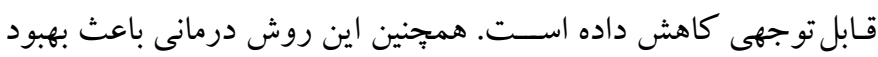

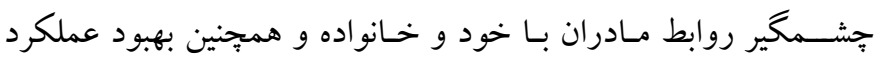
اجتماعى آنها شده است.

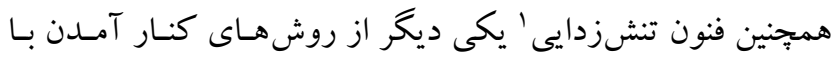

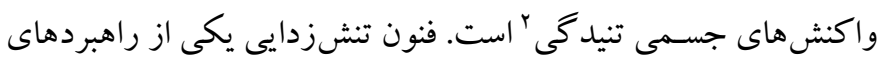

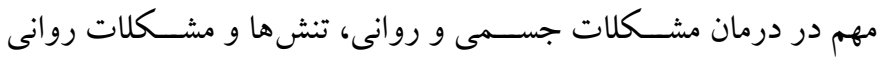

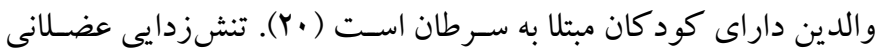

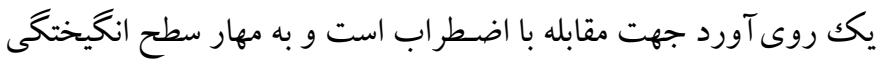

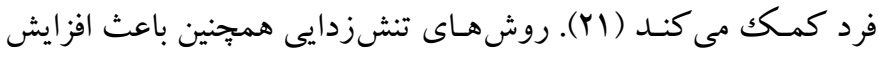

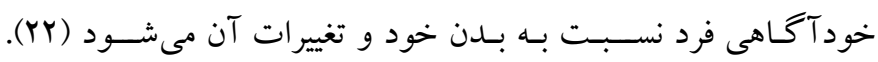

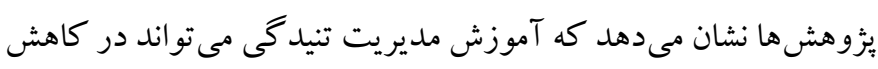

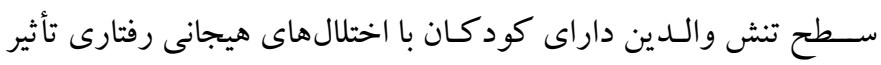

داشته باشد (Yr) - (ب).

يزوهشهاى مختلفى تأثير فنون تنشزدايى را بر تنيدگى و اضطراب

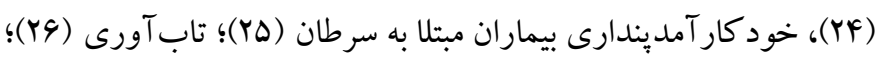
تنظيم هيجانى در بيمـاران ســرطانى (YV)؛ بهبود رابطه والد- كود كك و بهزيستى روانشـناختى مادران كود كان كمتو ان ذهنى (YN)؛ و همجِنين شـاخص هاى سلامت روان مانند افسردگى، اضطراب، و تنيدگى در ساير

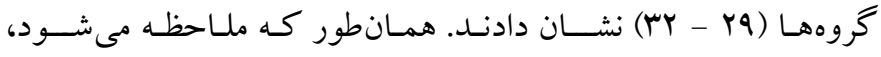

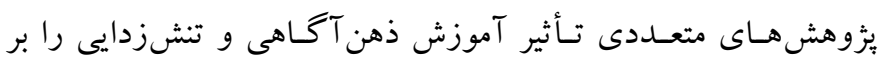
كاهش بريشانى هاى روانشناختى نشان دادهاند. هر دو روش درمان منجر

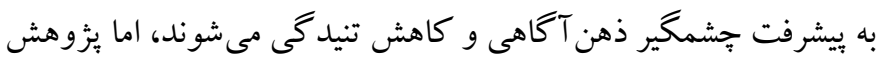

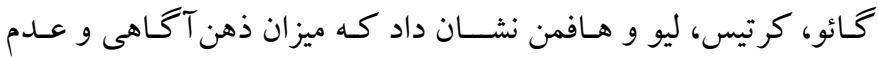

1. Relaxation Techniques 
r. برسسشنامه سـلامت عمومى كلدبرك و هيلر '. براى سـنجش سـلامت

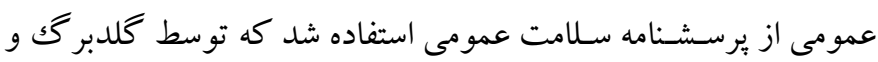

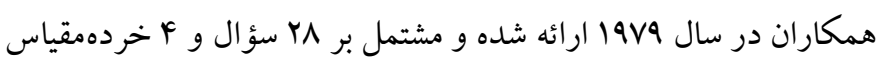

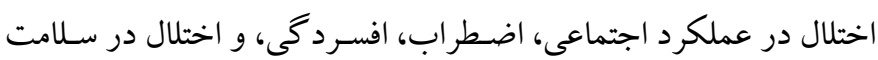

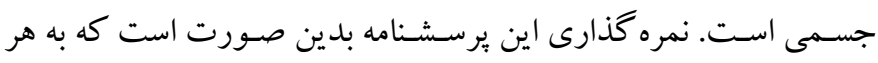

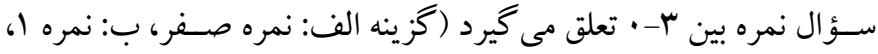

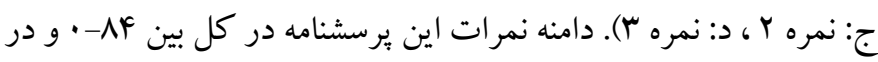
هر مقيـاس بين آY-• اســت. نمره برش براى نمره كـل ابزار سب تعريف شده است و كسب نمره بالاتر از اين عدد، نشانه وجود اختلال است (بس).

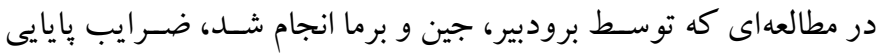

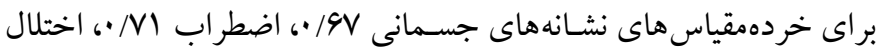

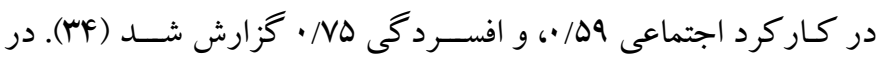

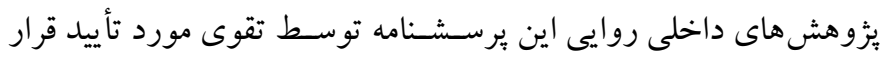

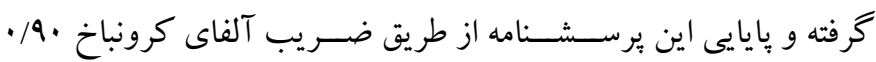

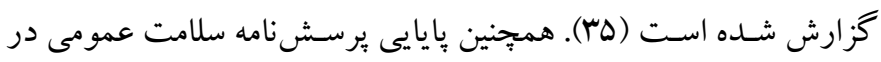
ايران توســط نجفى، صــولتى دهكردى و فروزبخش بـا روش آزمونآزمون مجدد (هو/•) و روايى آن با روش روايى محتوا، تأييد شده است

ج) معرفى برنامه هاى مداخلهاى

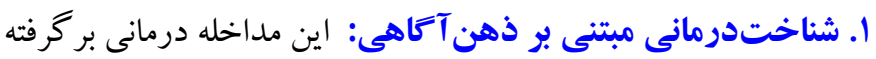

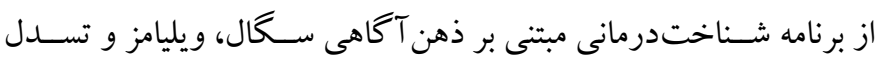

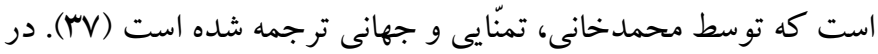
طى اين دوره درمانى، افراد مى آموزند كه روشهاى بسـيار متنوعى براى

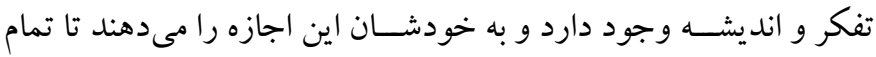

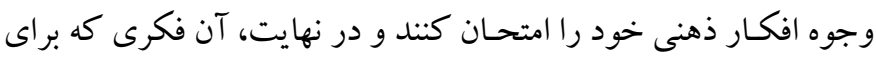

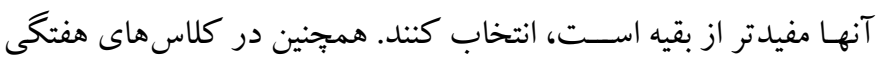

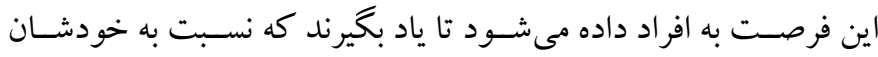

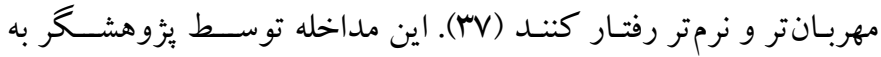

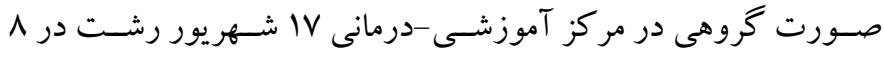

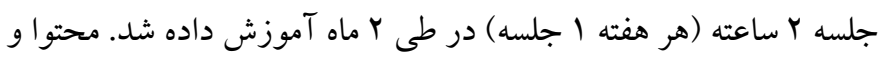
اهداف هر جلسه در جدول ا ارائه شده است.
تشـخص متخصصان مبنى بر داشتن بيمارى سرطان خون فرزند، رضايت

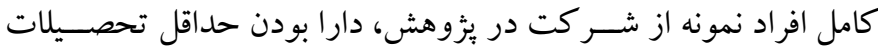

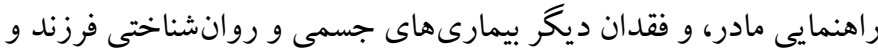

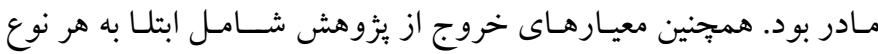
بيمـارىهاى مزمن مانند ديابت، بيمارىهاى قلبى و ريوى كودكى، ابتلا به

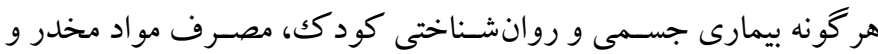

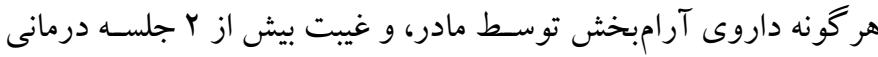

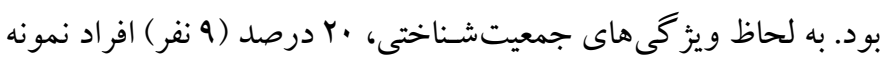

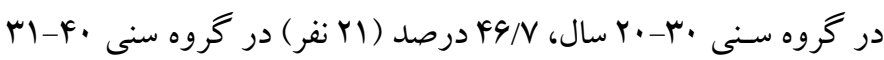

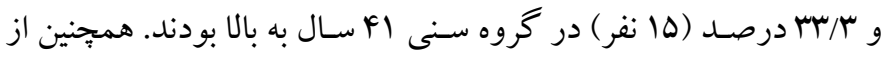

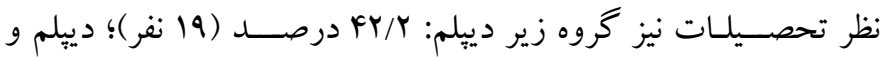

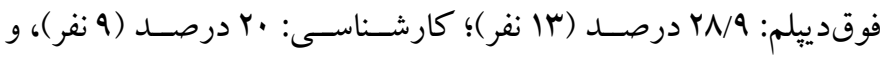

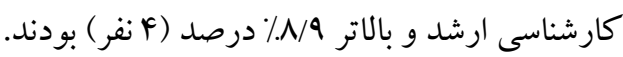

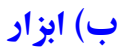
1. برسـشنامه جمعيتشناختى: شامل سوالاتى در مورد سن والدين، ميزان تحصيلات و وضعيت تأهل والدين، وضعيت شغلى و در آمدى خانو اده، سن و جنس كودك، مدت زمان تشخيص بيمارى كودكى، تعداد دفعات بسترى به دليل بيمارى از زمان تشخيص كودكى، و مر حله بيمارى، و نوع

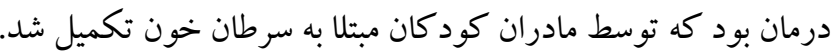
r. مصاحبه و آزما يش هاى تشخيصسى متخصص براى تشخيص سرطان:

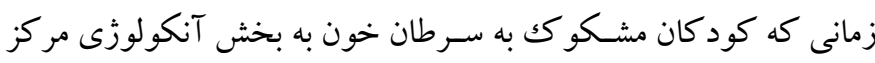

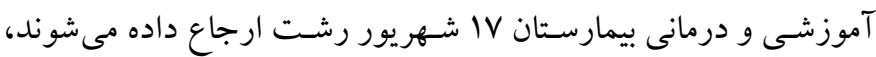

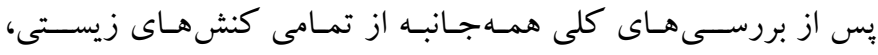

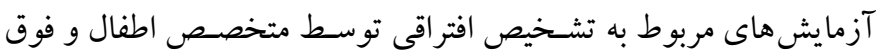

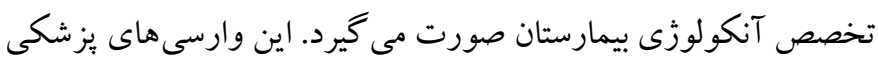

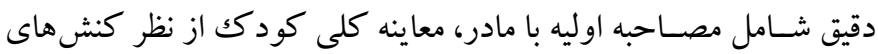

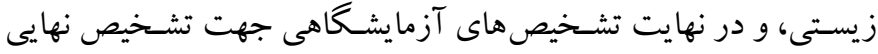
افتراقى مىباشـد. در هر صـورت همين روند ارزيابى و تشـخيص كامل

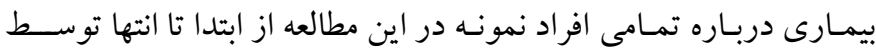
يزّوهشكر كه از كادر درمانى اين بيمارستان هستند، به طور دقيق تا مرحله انتخاب نهايى افراد شر كت كننده در ئزوهش، اجرا شد. 
جدول ا: برنامه شناختدرمانى مبتنى بر ذهن آكاهى

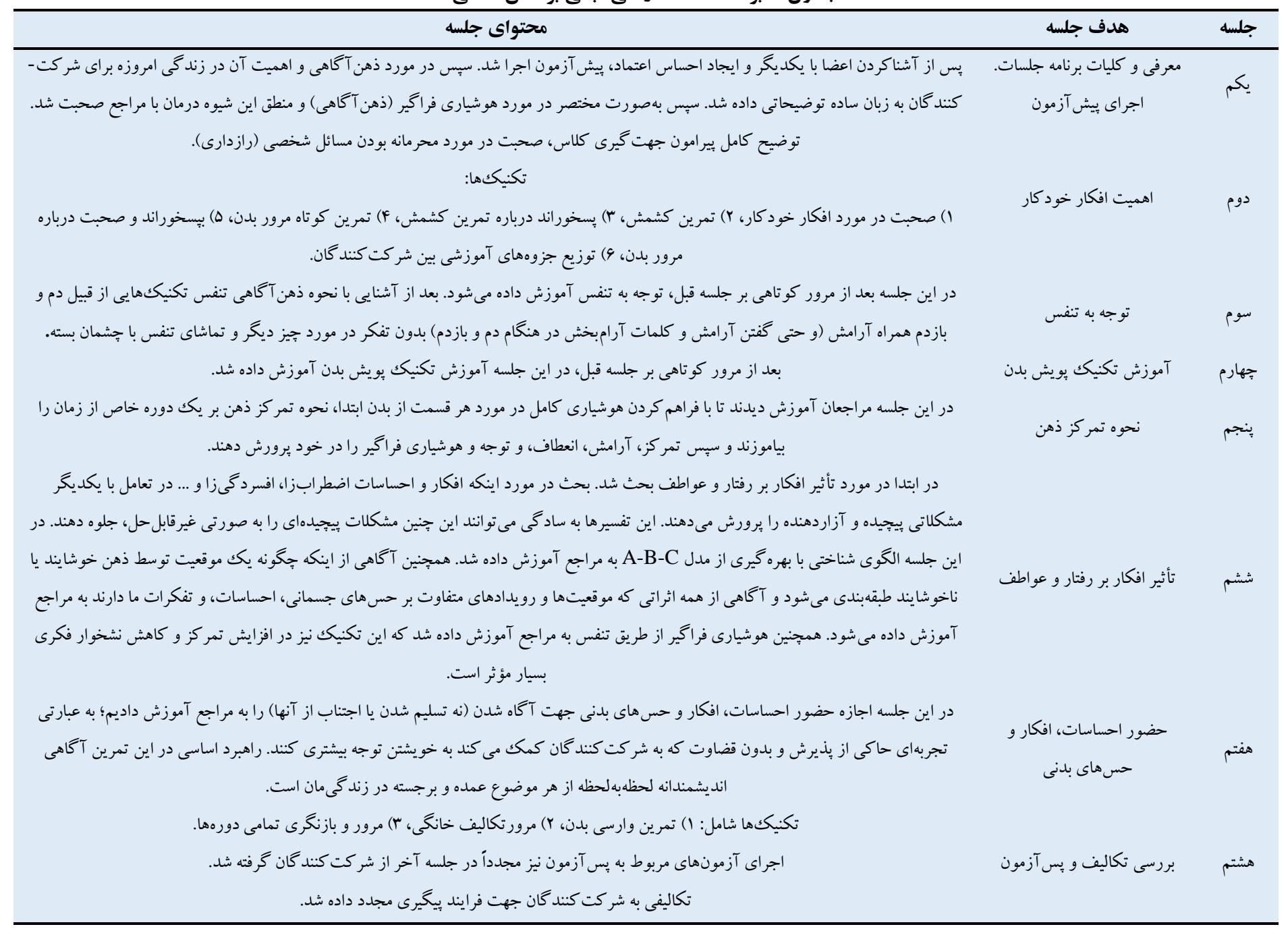

نشـسـتهاند جشمان خود را ببندند و · ا دقيقه اول هر جلسه به كرم كردن، از جملهه دســتور العمـل هـاى مربوط بـه تنشزدايى و تكنيككهاى تنفس اختصــاص داده شــــ. ســـس، در •له دقيقـه بعـد، تمرينـات مربوط بـه تنش زدايى عضــلانى مطابق با دســتور العمل هاى تنشـزدايى ارائه شــــ. مـاهيجِهـهـا از حـالت تنش به ســمت آرامش حركت مى كنند و به طور لحظهاى به آرامش كامل مىرسند. محتو او اهداف هر جلسه در جدول r ارائه شده است. r. تنشزدايى يُشرونـده عضــلانى ': مداخله تنشزدايى بيشرونده عضـلانى مورد اسـتفاده در اين يخزوهش بر گرفته از مداخلهاى اسـت كه توسط ادموند جاكوبسون ط طراحى و متعاقباً توسط برنشتاين و بوركويك إك اصـلاح شـده اسـت. روش هاى اسـتاندارد اسـتفاده از اين روش بر اساس

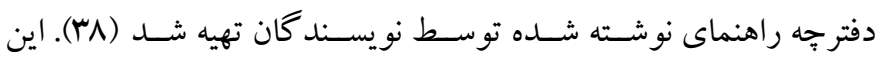
آموزش به صسورت گروهى توسط ئزوهشـر بر روى افراد نمونه كه به طور تصـادفى تحت اين آموزش قرار گر فته بودند در ^ جلسـه ا سـاعته انجام شد. در هر ^ جلسه از آزمودنى ها خواسته مىشد درحالى كه راحت 
جدول r: برنامه آموزشى تنشزدايى ييشرونده عضلانى

\begin{tabular}{|c|c|c|}
\hline محتواى جلسه & هدف جلسه & 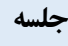 \\
\hline 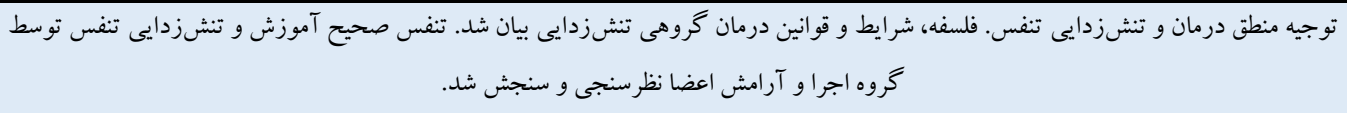 & توجيه منطق درمان و تنشزدايى & 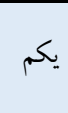 \\
\hline انقباض و رهايى براى 19 گروه از عضلات شامل دو عضله دست راست، دو عضله دست جب، سه عضله صورت، عضله گردن، عضله كتف و شانه، & تنشزدايى 19 گروه از عضلات & 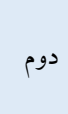 \\
\hline 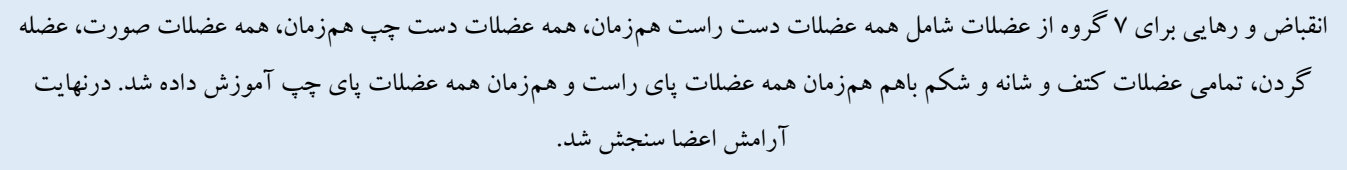 & تنشزدايى V كروه از عضلات & 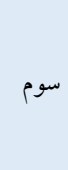 \\
\hline 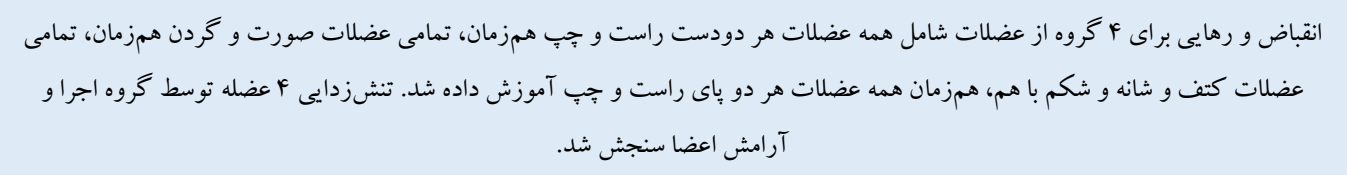 & تنشزدايى ع گرقوه از عضلات. & جهارم \\
\hline نحوه حذف انقباض عضلانى و ايجاد تمركز بر توانايى تقويت شده افراد گروه بر احساس تنش و آرامش، نحوه توجه بر هر گونه انقباض عضلانى و & آرامسازى از راه ياد آورى. & ينجم \\
\hline 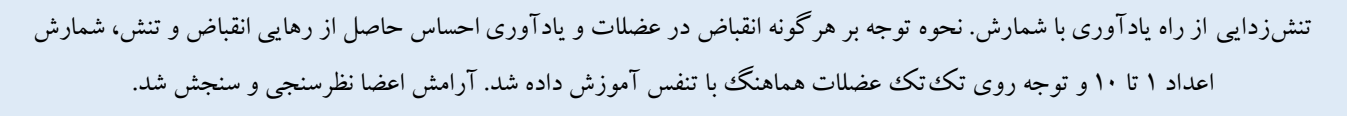 & تنشزدايى از راه يادآورى با شمارش & ششم \\
\hline شمارش اعداد ا تا ـ ا و توجه روى تكك تكك عضلات هماهنك با تنفس بدون كمكى گرفتن از عضله خاصى و بدون ياد آورى لحظه رهايى انقباض آموز & تنشزدايى از راه شمارش. & هفتم \\
\hline 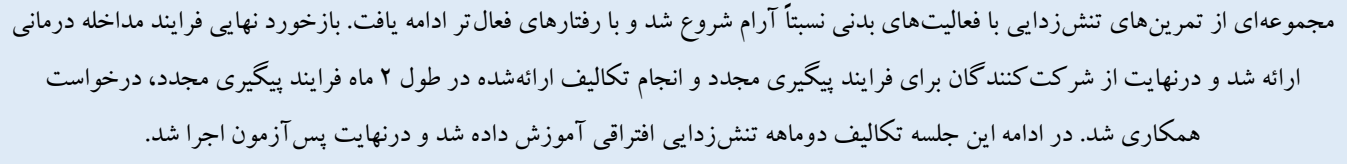 & بازخورد نهايى فرايند مداخله و & هشتم \\
\hline
\end{tabular}

كردند. در طول مدت مداخله درمانى براى Y گ گروه آزمايش، براى گروه كواه هيج آموزشـى ارائه نشــد. يس از انجام فرايند مداخله درمانى، از ب

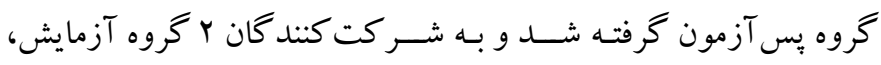

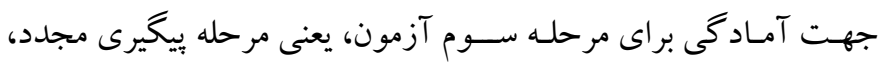

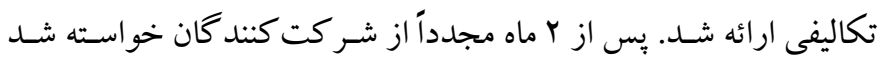
برســـنامه سـلامت عمومى را تكميل كنتد. به جهت حفظ رعايت اصول اخلاقى در اين يثزوهش سـى شـد تا جمع آورى اطلاعات در هر م مرحله

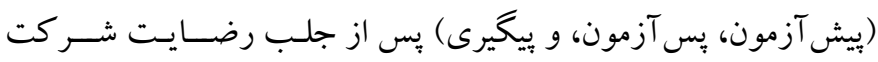
كنند كان انجام شود. همجنين به شر كت كنند كان اطمينان از رازدارى در حفظ اطلاعات شـخصسى و عدم ارائه نتايج بدون قيد نام و مشــخصـات شناسنامهاى افراد، داده شد. يس از F ماه آموزش و بيخيرى، نمره گذارى يرسشنامهها و تحليل دادهها با روش تحليل واريانس اندازه كيرى مكرر و

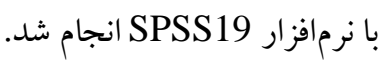

د) روش اجرا: بس از تصويب طرح در كميته يثوهشى دانشگاه و كسب مجوزهاى للازم جهت انجام يثوهش، مراحل اخذ كد اخلاق انجام شــد. سـبس بر كه همكارى از دانشـكاه آزاد رشـت اخذ و به مركز آموزشسى درمانى VI شهريور كود كان اين شـهر ارائه شد. يس از دريافت فهرست بيمارانى كه به مركز مر اجعه نموده و توسط متخصصان به بيمارى سرطان خون مبتلا بودند، با والدين اين كود كان تماس كر فته شـــــ و مادرانى كه تمايل به شــركت در بثزوهش را داشـتند، جهت حضــور در برنامهاى مــاخلـهاى بـه مركز دعوت شـــند. يس از بررســى معيارهاى ورود و خروج، ها نفر از اين مادران به شيوه در دسترس انتخاب شده و با انتساب

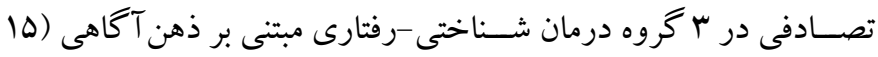
نفر )، آموزش تنشزدايى (ها نفر ) و گواه (ها نفر ) جـايدهى شـــدند. از

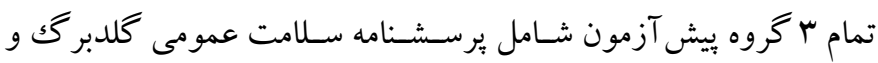

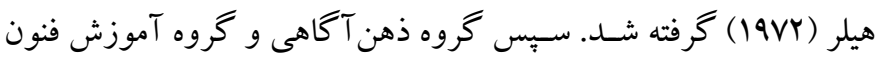
تنشزدايى به صورت مجزا و در مجموع به مدت Y ماه، آموزش دريافت 
يافته ها

ميانگين و انحر اف اسـتاندارد نمرات متغيرهاى يزوهش به تفكيكك ســه

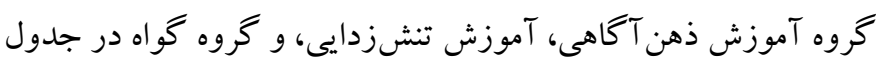

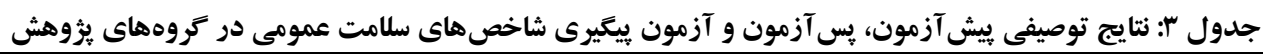

\begin{tabular}{|c|c|c|c|c|c|c|c|c|}
\hline \multicolumn{2}{|c|}{ ييغيرى } & \multicolumn{2}{|c|}{ پس آزمون } & \multicolumn{2}{|c|}{ يِيش آزمون } & \multirow[t]{2}{*}{ كروه } & \multirow{2}{*}{ مقياسها } & \multirow{2}{*}{ متغير } \\
\hline SD & ميانغين & SD & ميانكين & SD & ميانغين & & & \\
\hline r/৭9 & Ir/A9 & $F / \mu^{\prime}$ & $1 r / 94$ & $1 / \Delta r$ & $\mid F / Y$. & ذهن آ كاهى & & \\
\hline$r / \cdot r$ & $11 / \Delta r$ & $1 / Y \Lambda$ & $9 / V \Psi$ & $1 / 44$ & $|f /| r$ & تنشزدايى & شكايات جسمانى & \\
\hline$\Delta / 4 i$ & $10 / F V$ & $\Delta / \Delta r$ & $10 / r$. & $1 / \Delta r$ & $1 F / .9$ & كواه & & \\
\hline $1 / r$. & $9 / Y$. & $1 / r V$ & $9 / \wedge$. & $r / \Delta Q$ & $\mid F / A$. & ذهن آ آهى & & \\
\hline r/TD & $1 . / 4$. & $r / I V$ & 1. & $1 / 11$ & $10 / 9 \mathrm{~V}$ & تنشزدايى & اضطراب & \\
\hline r/af & $\mid r / 4$. & F/qV & $\mid F / r q$ & $1 / A V$ & $10 / \pi r$ & كواه & & \\
\hline$r / Y I$ & $1 \cdot / \wedge$. & $1 / I V$ & $9 / \pi$ & $1 / 9 \mathrm{~V}$ & אות & ذهن آ گاهى & & ت عمومى \\
\hline $9 / \mu F$ & $\mid r / 4$. & $r / 4 q$ & $Q / Y V$ & $1 / 99$ & $\mid r / r$ & تنشزدايى & عدم كاركرد اجتماعى & \\
\hline$f / r q$ & $1 . / r$. & $f / \cdot F$ & 1.194 & سז/T & 11 & كواه & & \\
\hline r/Tq & $1 . \% \mathrm{~V}$ & $\mid / r 1$ & $9 / \%$. & $1 / 90$ & 19 & ذهن آ كاهى & & \\
\hline$\cdot / \wedge 9$ & $1 \pi / T$. & $r / r q$ & $\Lambda / \wedge \vee$ & $r / 9 \Lambda$ & $\mid f / Y$ & تنش زدايى & افسردگى & \\
\hline$\Delta / f$. & 1Q/Dr & D/ه & $\mid F / N$ & Y/YG & $\mid r / \Delta r$ & كواه & & \\
\hline
\end{tabular}

كروهى بود. بنابر اين طرح مورد استفاده طرح درون-بين آزمودنى' است.

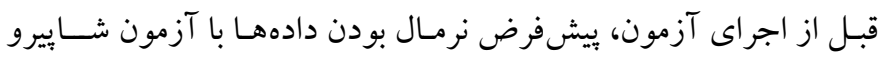

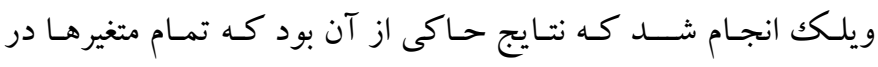

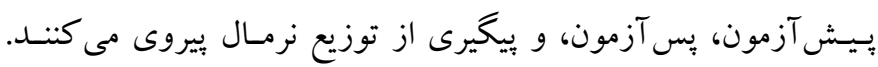

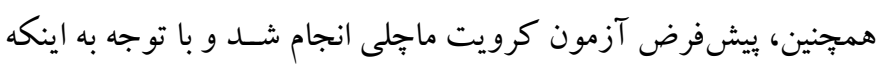

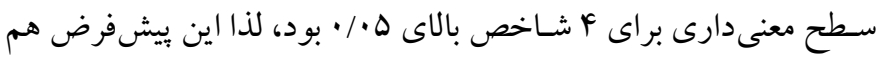

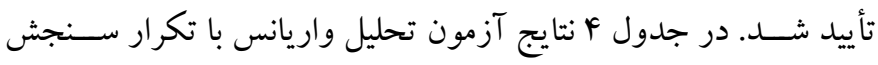
براى گروهها ارائه شده است.
نتـايج توصـيفى بيش آزمون، بِ آزمون، و وييخيرى شــاخص هـاى

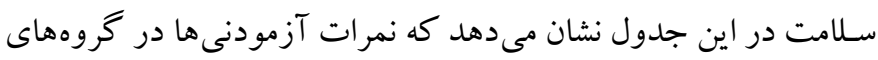

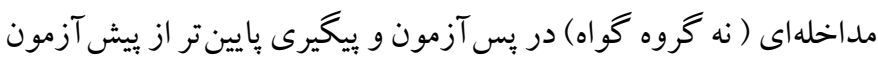

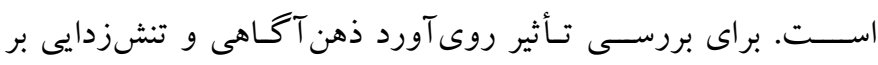

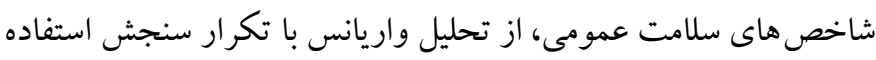

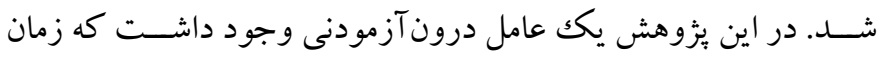

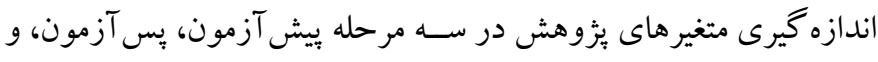

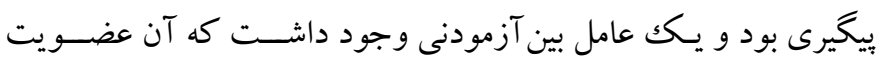

جدول ع: نتايج آزمون تحليل واريانس با اندازههاى مكرر جهت بررسى تفاوت تروهها در شاخصهاى سلامت عمومى در سه مرحله ييشآزمون، يسآزمون، و يِيَيرى

\begin{tabular}{|c|c|c|c|c|c|c|c|}
\hline اندازه اثر & Sig & Foار Fار & ميانكين مجذورات & درجه آزادى & مجموع مجذورات & منابع تغييرات & متغير \\
\hline.$/$ TF. & $\%$ & 9/9KY & $110 / 119$ & $r$ & $r \mu / r r V$ & تفاوت بين گروهى & \multirow{3}{*}{ شسمانى } \\
\hline.$/ .49$ & $\cdot / 1 \wedge \Delta$ & I/Vr. & $10 / 999$ & r & 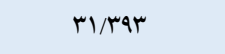 & تفاوت درونگروهى (مراحل) & \\
\hline.$/ F A$ & $.1 \cdot 9$ & r/GFr & 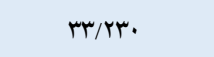 & F & $|r r / 9| 9$ & تعامل مراحل با گروه & \\
\hline . & $\cdot \cdots$ & $1 . / r r^{4}$ & $q V / 4 r$. & r & 19F/ADQ & تفاوت بين گروهى & اضطراب \\
\hline
\end{tabular}




\begin{tabular}{|c|c|c|c|c|c|c|c|}
\hline ./QY9 & $\cdot / \cdots$ & $\$ 9 / 911$ & r৭q/.r. & r & $\Delta 9 / / \cdot \Delta q$ & تفاوت درون گروهى (مراحل) & \multirow{5}{*}{ عدم كاركرد } \\
\hline.$/ 191$ &.$/ .4$ & $r / T r \Delta$ & $\mathrm{rV} / \mathrm{Tr}$. & r & $1 . N / 019$ & تعامل مراحل با گروه & \\
\hline.$/$ Vvo &.$/ \cdot 11$ & q/qar & $V r / \Lambda .$. & r & $\mid F \Delta / 9 .$. & تفاوت بين گروهى & \\
\hline 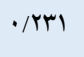 & $\cdot \cdots$ & $|r / 9|$. & 1. r/Arr & r & $r \cdot \Delta / 9 F F$ & تفاوت درون گروهى (مراحل) & \\
\hline.$/ 199$ &.$/ .1$ & $\Delta / 11 r$ & $41 / 9 \wedge 9$ & $r$ & $199 / \mathrm{NDS}$ & تعامل مراحل با كروه & \\
\hline$\cdot / \mu 41$ & $\cdot \cdots$ & $1 \cdot / 199$ & IVq/ $\cdot V F$ & r & TAN/IFA & تفاوت بين گروهى & \\
\hline$\cdot / \wedge F$ & / ro & r/AV. & FY/YVYF & r & $\Lambda F / \Delta F \wedge$ & تفاوت درون گروهى (مراحل) & افسردخى \\
\hline.$/ 1 \Delta r$ & $\bullet \cdot \cdot v$ & r/N99 & $F|/| F \mid$ & r & $19 \% / \Delta 94$ & تعامل مراحل با گروه & \\
\hline
\end{tabular}

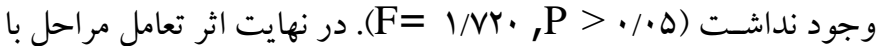

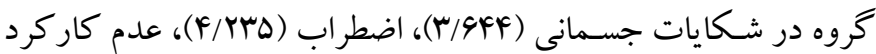

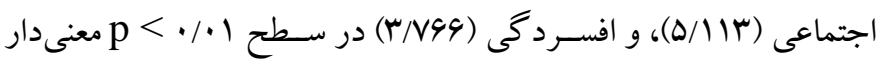

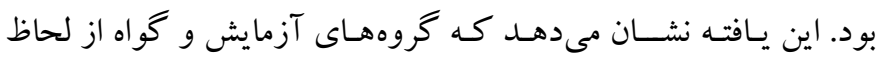

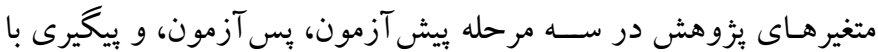

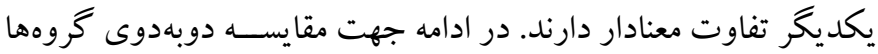

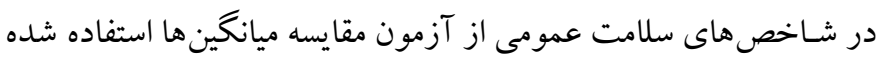
است كه نتايج آن در جدول ها ارائه شده است.
همانطور كه در جدول بالا نشان داده شده است، ميزان F تفاوتهاى

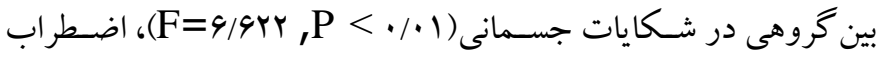

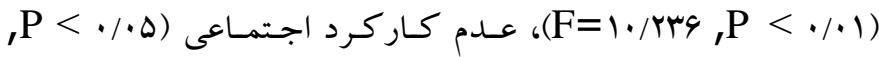
(F=f/Far

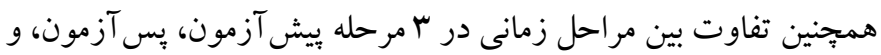

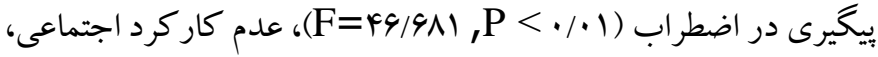

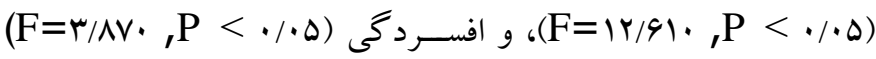
معنى دار بود. بين شـكـايات جسـمانى در مراحل مختلف زمانى تفاوت

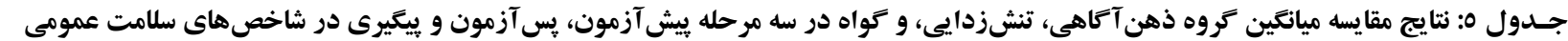

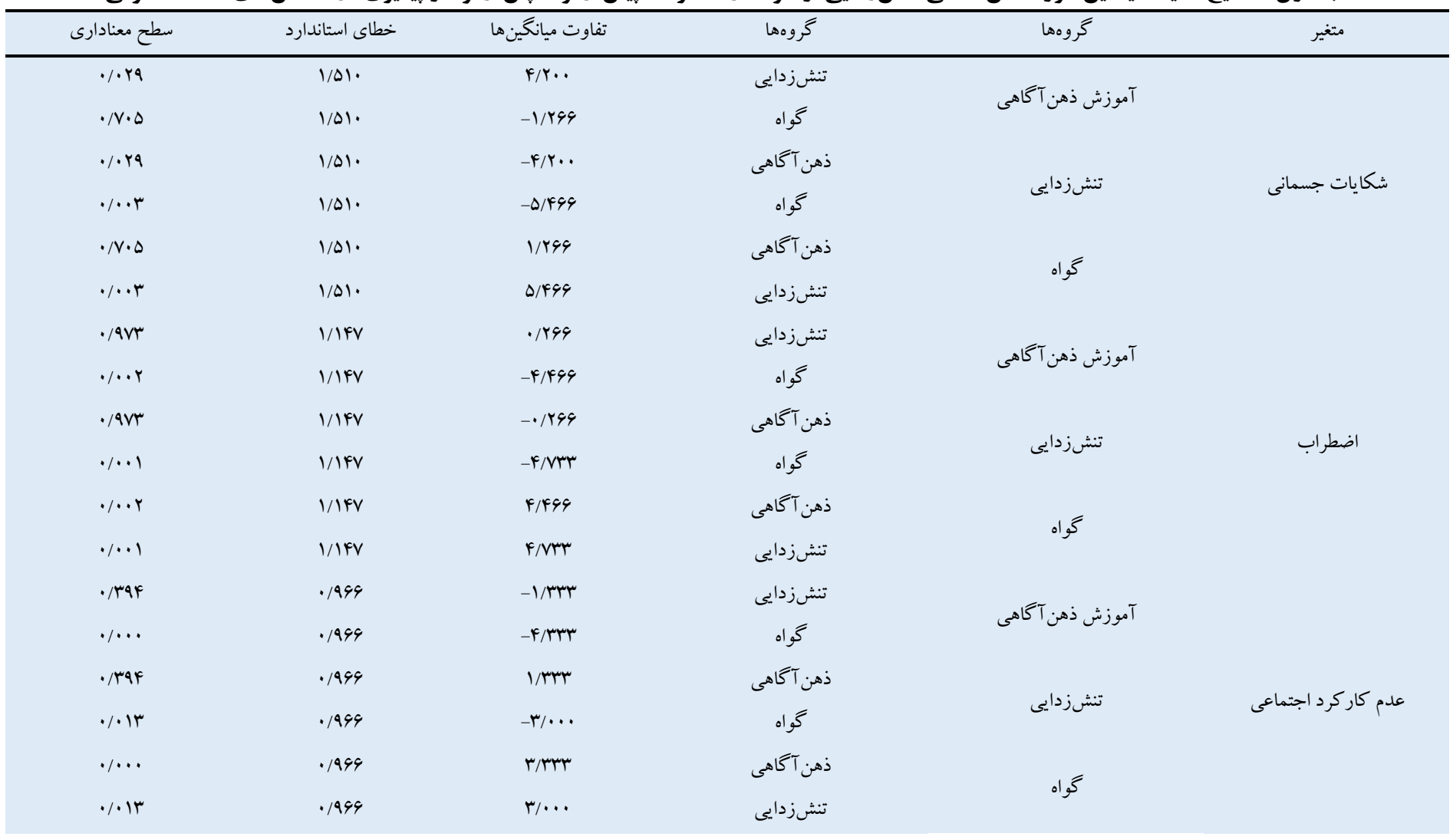




\begin{tabular}{|c|c|c|c|c|c|}
\hline - Na. & $1 / T \Delta F$ & (arr & تنشزدايى & \multirow{2}{*}{ آموزش ذهن آكاهى } & \multirow{6}{*}{ افسردگى } \\
\hline$\% r$ & $1 / r \Delta F$ & $-\Delta / 1 T \Gamma$ & كواه & & \\
\hline •/va. & $1 / T \Delta F$ & - & ذهن آكاهى & \multirow{2}{*}{ تنشزدايى } & \\
\hline$\cdot \cdots$ & $1 / T \Delta F$ & -91.94 & كواه & & \\
\hline$\% r$ & $1 / r \Delta F$ & سח/Iه & ذهن آكاهى & \multirow{2}{*}{ كواه } & \\
\hline$\cdot \%$ & $1 / r \Delta F$ & 91.94 & تنشزدايى & & \\
\hline
\end{tabular}

آريايوران، ابوالقاسـمى و احدى (IV) همســو اســت. در همين راسـتا،

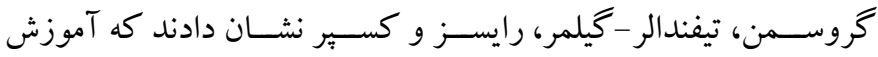

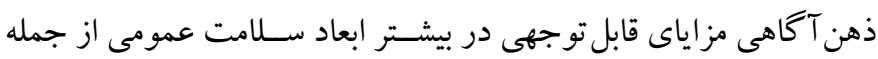

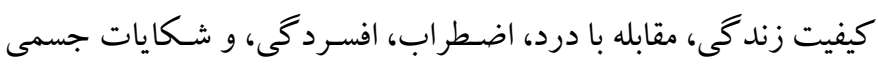

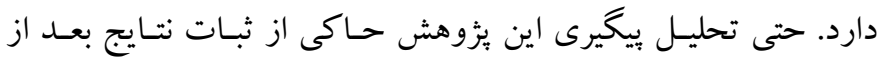

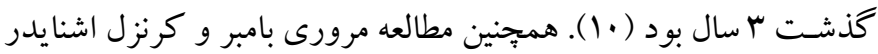

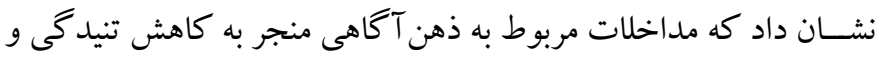

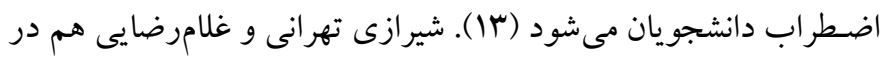
ايران اثربخشى اين درمان را بر سلامت عمومى مادارن كود كان كمتونوان

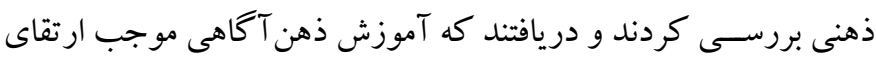

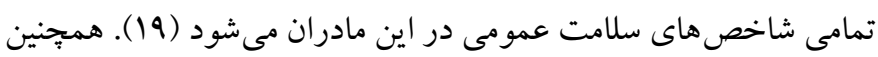

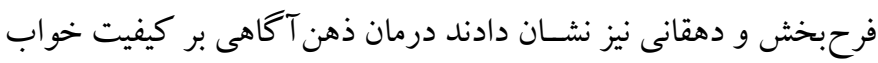

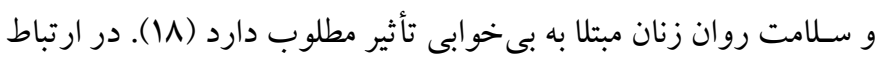

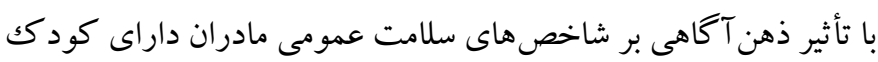

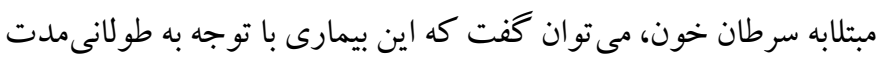

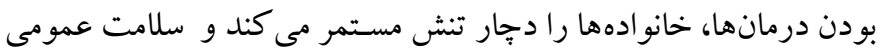

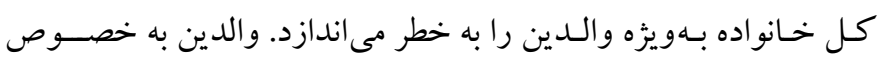

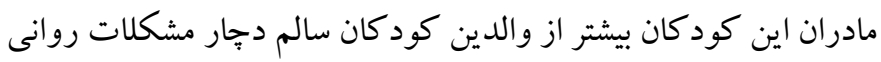
هسـتندو در نتيجه تشـخيص سـرطان و فرايند درمان آن، تأثير منفى در محيط خانو اده بهجا مى گذارد (Y) (r). در تبيين اين يـافته مى توان گفـت كه افزايش ذهن دهن آكاهى با افزايش

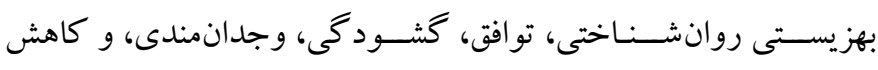

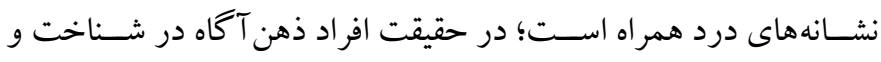

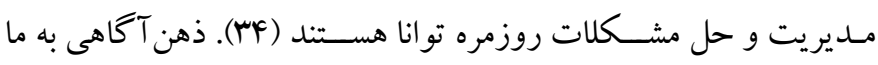
يارى مىدهد تا اين نكته را در كك كنيم كه هيجانهاى منفى ممكن است رخ دهد، اما آنها جزء ثابت و دائمى شخصيت نيستند. همجنين به فرد اين
جـــدول هـ مقايسه ميانخين هاى افتر اقى نمرههاى شاخص هاى سلامت

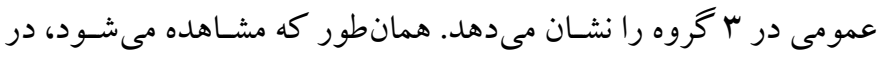

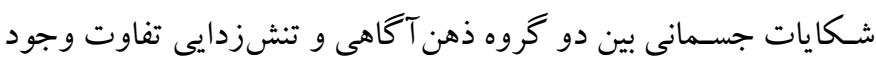

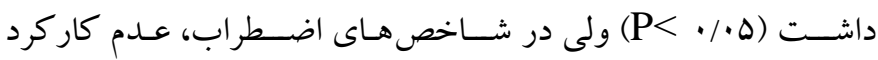

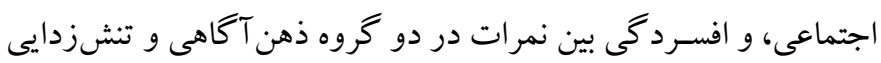

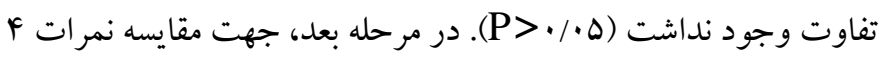

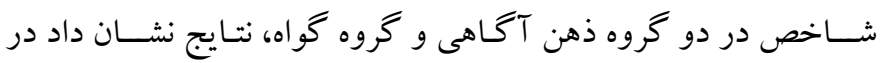

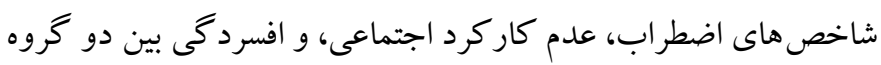

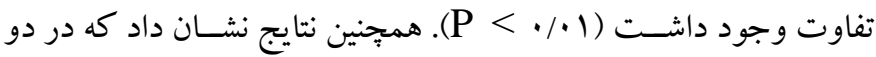

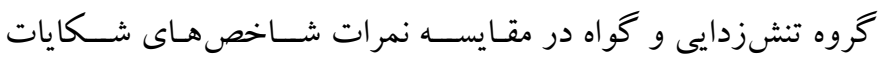

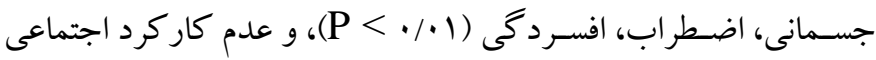

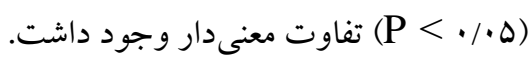

\section{بحث و نتيجه تيرى}

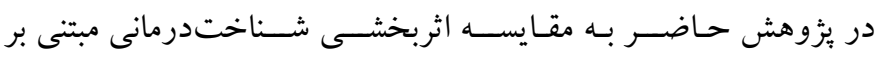

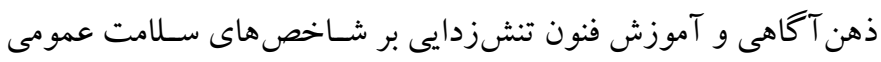

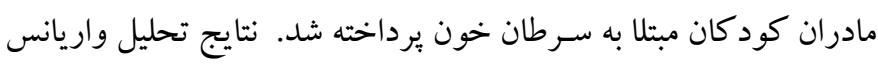

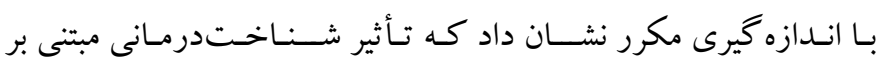

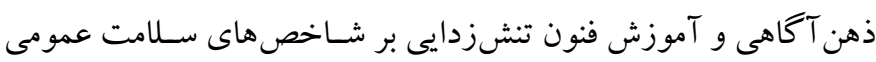

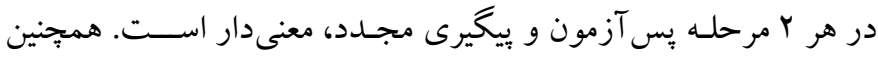

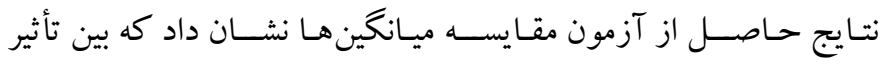

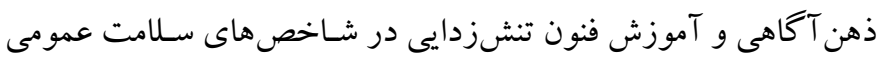

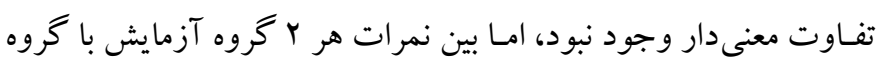
كو اه تفاوت معنى دار مشاهده شد.

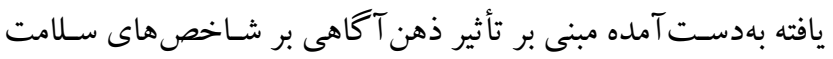

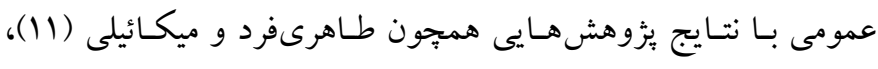

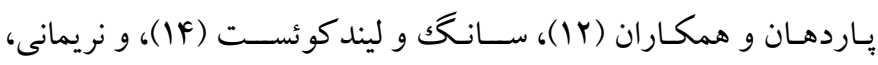


افزايش خود آكاهى فرد نسبت به بدن خود و تغييرات آن (Yr) و مديريت

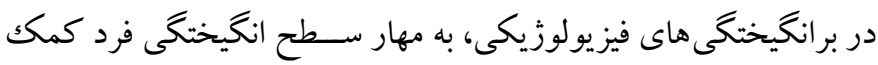

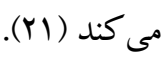

همجنين در تبينى ديخر مى توان كفت كه تنشزدايى با ايجاد تعادل

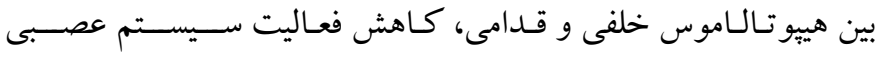

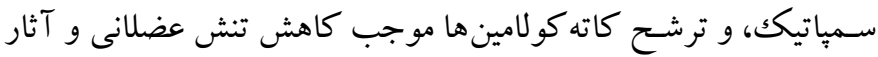

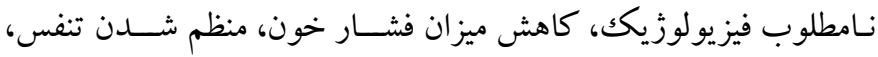

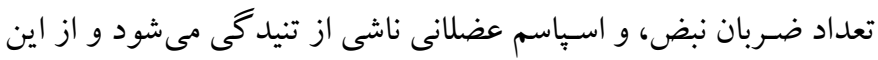

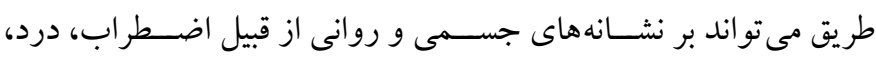

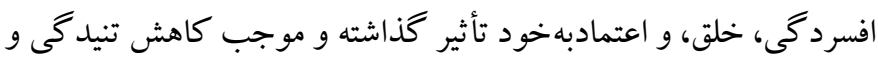

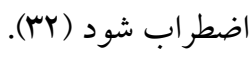

در نهايـت بر اســاس بزوهش گائو و همكاران (YY)، در تبيين عدم

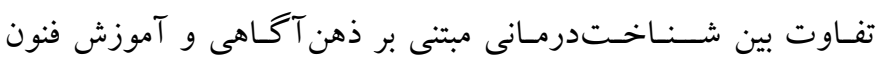

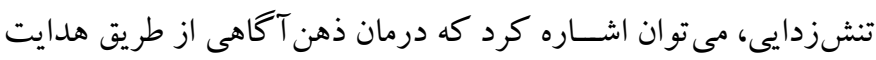

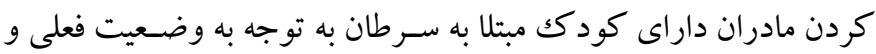

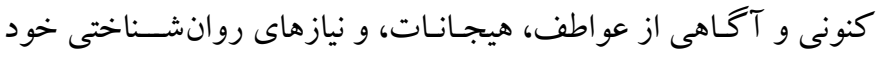
باعث مى شود اين افر اد به خود آكاهى عميقى دست يافته و توجه بيشترى

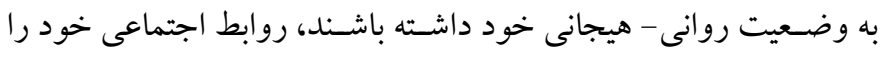

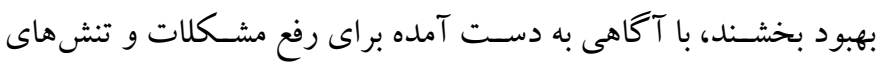

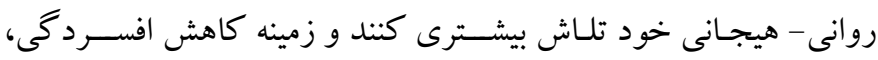
اضطراب، نارساكنشورى اجتماعى، و شكايات جسمانى را فراهم كنند؛

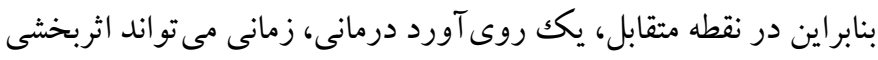

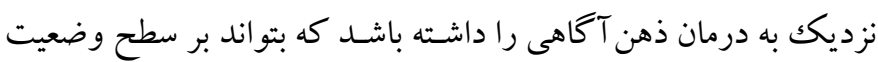

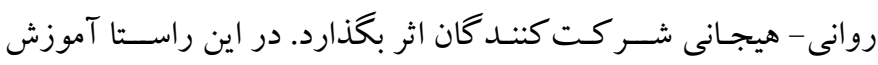
تنشزدايى از طريق مديريت و تغييرى كه بر سطح وضعيت فيزيولوزيكى

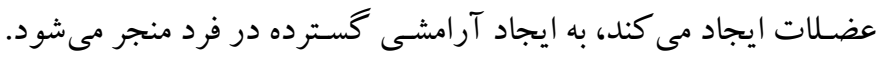
طبق نظر جاكوبسون وقتى شخصى دجار آشفتگى، فشار، و تنش روانى هيجانى اسـت، تنشزدايى نقطه مقابل تنش اســت و با غلبه بر تنشهاى

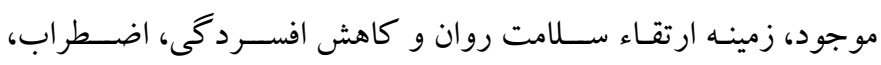
نارسـاكنش ورى جسـمانى، و شـكايات جسـمانى مهيا مى شـود؛؛ بنابر اين

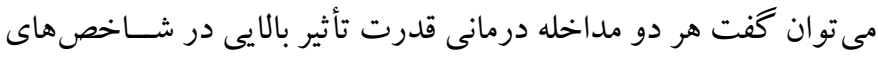

امكان را مىدهد تا بهجاى آن كه به رويدادها بهطور غيرارادى و بى تأمل

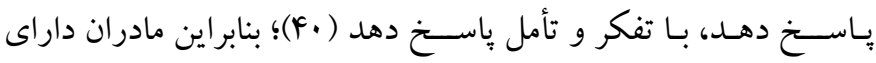

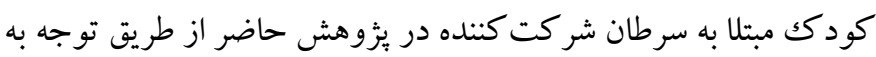

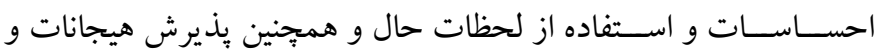
عو اطف خود توانستهاند بهطور بهينه از ظرفيت ذهن آكاهى خود استفاده كرده و سلامت روانى خود را ارتقا دهند. همجينين يافته بهدست آمده در اين مطالعه مبنى بر تأثير آموزش فنون

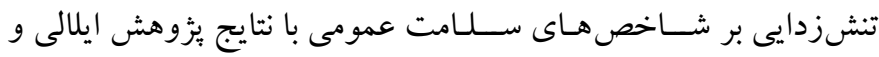

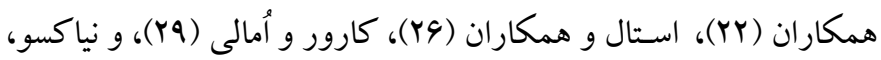

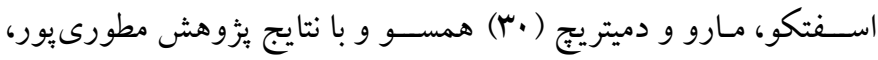

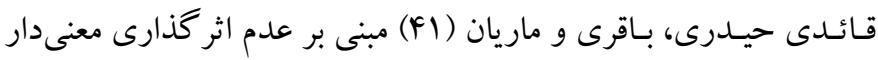
آموزش فنون تنشزدايى بر سلامت عمومى، ناهمسو است.

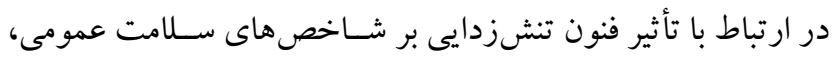

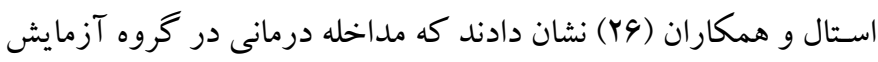
به بهرهورى بيشتر از نظر سلامت و تنشزدايى اعصاب مىانجامد. همجنين

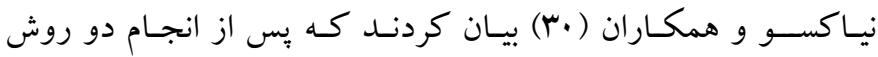

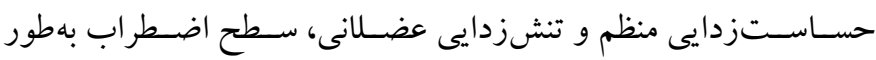

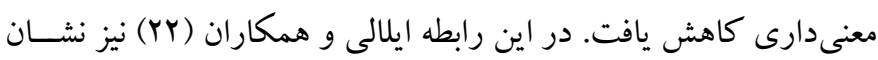

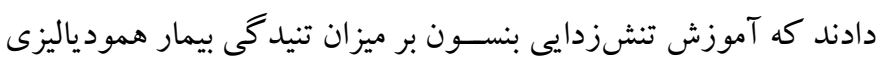
بيمارستانهاى امام خمينى (ره) و فاطمه زهرا (س) سارى مؤثر بوده است.

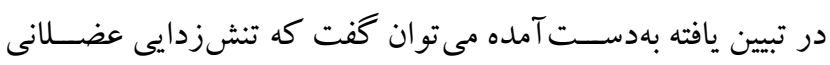

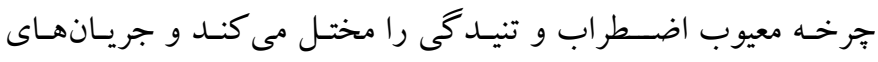

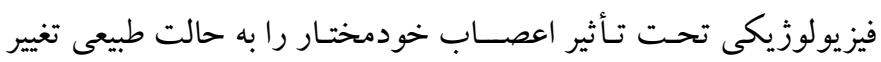

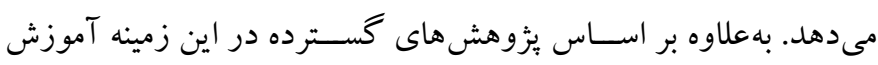

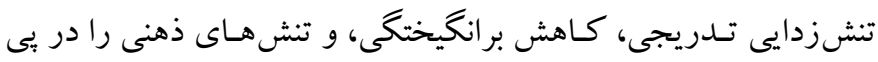

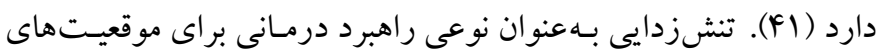

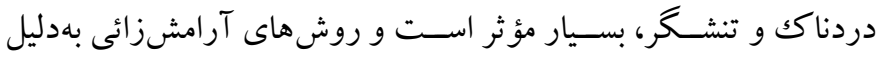
ايجاد آرامش، احسـاس لذتبخش، احسـاس خوب بودن ون و فعال كردن

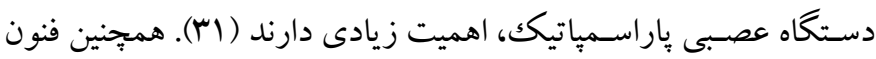

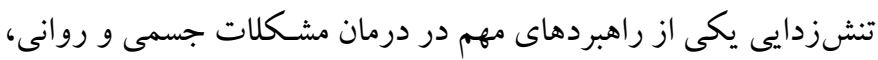

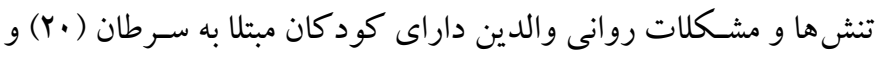

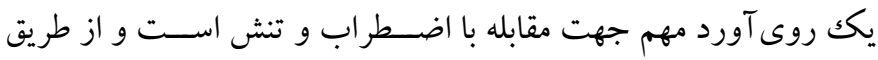


شـيوههاى درمانى را براى والدين و ساير افراد مراقبت كننده آنها، در نظر

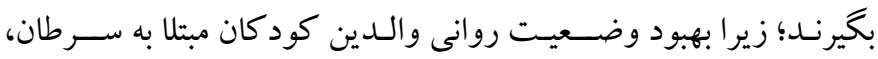

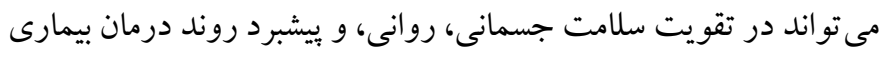
كودكى، تأثير زيادى داشته باشد.

IR. IAU. RASHT. تشــكر و قـدردانى: اين يُوهش بـا كـد اخلاق REC. 1395.57 روانشـاسى عمومى دانشگاه آزاد واحد رشت است. همجنين مجوز اجراى آن

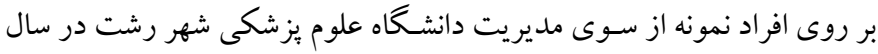

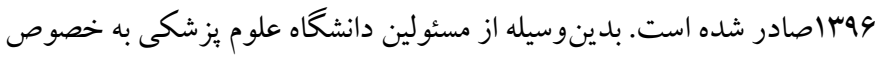

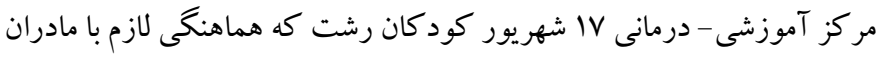

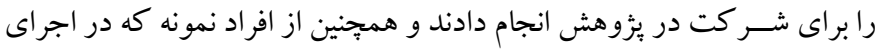
اين طرح به ما كمك كردند تشكر و قدردانى مى دشود. تضـاد منافع: در اين مقاله تضــاد منافع براى هيج كدام از نويســد كان وجود

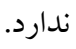

سلامت عمومى داشته و به اين دليل تفاوت بين دو مداخله در اين مطالعه،

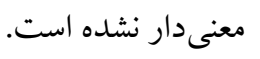
يثزوهش حاضـر با محدوديت هايى مو اجه بود، مانند: استفاده از طرح

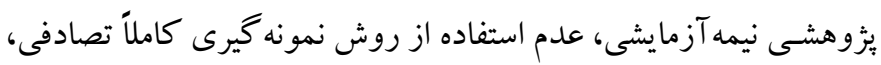

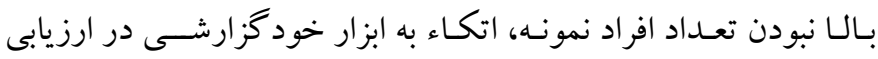

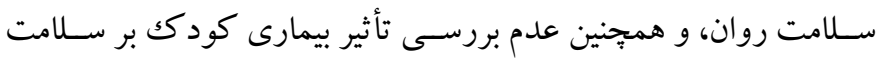

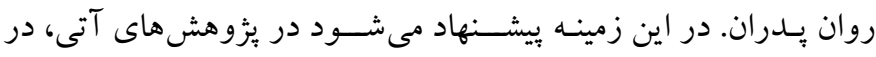

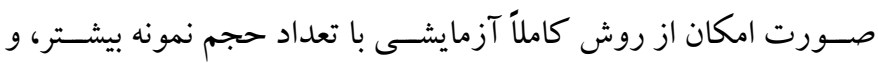
همجنين انجام اين مداخلات براى بدران كود كان مبتلا به ســرطان خون،

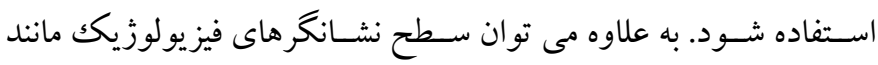

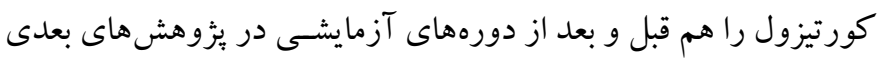

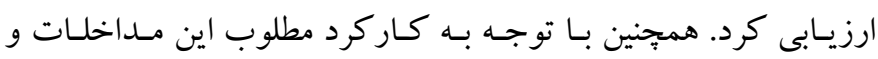

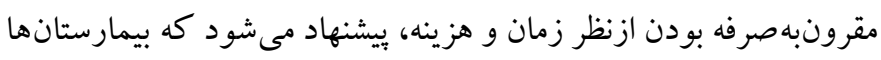
و مراكز درمانى فعال در درمان كود كان مبتلا به سـرطان، اسـتفاده از اين 


\section{References}

1. Sabouri S, Esmaily H, Shahid Sales S, Emadi M. Determining related factors to survival of colorectal cancer patients using cox regression. Medical Journal of Mashhad University of Medical Sciences. 2018; 61(4): 1083-1092. [Persian]. [Link]

2. Hunger SP, Teachey DT, Grupp S, Aplenc R. 93 Childhood leukemia. In: Niederhuber JE, Armitage JO, Kastan MB, Doroshow JH, Tepper JE, editors. Abeloff's clinical oncology (sixth edition). Philadelphia: Content Repository Only; 2020, pp: 1748-1764.e4. [Link]

3. Amani O, Mazaheri MA, Nejati V, Shamsian BS. Effect of cognitive rehabilitation on executive functions in adolescent survivors of leukemia: a randomized and controlled clinical trial. Archives of Rehabilitation. 2017; 18(1): 73-82. [Persian]. [Link]

4. Harper FWK, Albrecht TL, Trentacosta CJ, Taub JW, Phipps S, Penner LA. Understanding differences in the long-term psychosocial adjustment of pediatric cancer patients and their parents: an individual differences resources model. Transl Behav Med. 2019; 9(3): 514522. [Link]

5. Rashidi F, Ghodsi A, Shafi Abadi A. The effect of illogical beliefs on mental health of the girl students of high schools in Tehran. The Journal of Modern Thoughts in Education. 2010; 5(2): 49-65. [Persian]. [Link]

6. Rashidi MA, Pournajaf A, Kazemy M, Kaikhavani S. Evaluating general health status using Goldberg's general health questionnaire among the staff of Ilam university of medical sciences in 2015. Scientific Journal of Ilam University of Medical Sciences. 2018; 26(3): 16-26. [Persian]. [Link]

7. Yavarian R, Haghighi M, Ramezanpour A, Radfar M. A survey on relationship between perfectionism and mental health in students of Urmia university of medical sciences. Journal of Urmia Nursing and Midwifery Faculty. 2017; 15(7): 497-503. [Persian]. [Link]

8. Bishop SR, Lau M, Shapiro S, Carlson L, Anderson ND, Carmody J, et al. Mindfulness: a proposed operational definition. Clinical Psychology: Science and Practice. 2004; 11(3): 230-241. [Link]

9. Nabipoor Gisi S, Rafieepoor A, Haji Alizadeh K. Effectiveness of mindfulness-based cognitive therapy (MBCT) on psychological symptoms in patients with cancer. Journal of Research in Behavioural Sciences. 2018; 16(3): 333-343. [Persian]. [Link]

10. Grossman P, Tiefenthaler-Gilmer U, Raysz A, Kesper U. Mindfulness training as an intervention for fibromyalgia: evidence of postintervention and 3-year follow-up benefits in well-being. Psychother Psychosom. 2007; 76(4): 226-233. [Link]

11. Taherifard M, Mikaeili N. The effectiveness of cognition-based mindfulness therapy on social anxiety, resilience and emotion regulation in women victims of domestic violence. Thoughts and Behavior in Clinical Psychology. 2019; 13(51): 17-26. [Persian]. [Link]

12. Pradhan EK, Baumgarten $M$, Langenberg $P$, Handwerger B, Gilpin AK, Magyari T, et al. Effect of mindfulness-based stress reduction in rheumatoid arthritis patients. Arthritis Rheum. 2007; 57(7): 11341142. [Link]

13. Bamber MD, Kraenzle Schneider J. Mindfulnessbased meditation to decrease stress and anxiety in college students: A narrative synthesis of the research. Educational Research Review. 2016; 18: 1-32. [Link]

14. Song Y, Lindquist R. Effects of mindfulness-based stress reduction on depression, anxiety, stress and mindfulness in Korean nursing students. Nurse Educ Today. 2015; 35(1): 86-90. [Link]

15. Mehranfar M, Younesi J, Banihashem A. Effectiveness of Mindfulness-Based Cognitive Therapy on Reduction of Depression and Anxiety Symptoms in Mothers of Children with Cancer. Iran J Cancer Prev. 2012; 5(1): 1-9. [Link]

16. Valipour M, Hosseinian S, Pourshahriari M. The effectiveness of cognitive therapy based on mindfulness on children's behavioral problems. Journal of Child Mental Health. 2018; 4(4): 34-45. [Persian]. [Link]

17. Narimani M, Ariapouran S, Abolghasemi A, Ahadi B. The comparison of the effectiveness of mindfulness and emotion regulation training on mental health in chemical weapon victims. Journal of Clinical Psychology. 2010; 2(4): 61-71. [Persian]. [Link]

18. Farahbakhsh A, Dehghani F. Effectiveness of mindfulness therapy in sleep quality and mental health of women with insomnia disorder. Journal of Torbat Heydariyeh University of Medical Sciences. 2016; 4(3): 8-15. [Persian]. [Link]

19. Shirazitehrani AR, Gholamrezaee S. Effectiveness of mindfulness based stress reduction on the mental health of mothers who have educable mentally retarded children. Exceptional Education Journal. 2016; 9(137): 5-16. [Persian]. [Link]

20. Abdollahi Fard S, Dolatian M, Heshmat R, Alavi Majd H. Effect of foot reflexology on physical and psychological symptoms of premenstrual syndrome. Pajoohandeh Journal. 2013; 18(1): 8-15. [Persian]. [Link] 
21. Ahmadi E, Farsi A, Vaez Mousavi MK. Effect of biofeedback and relaxation training on statecompetitive anxiety among football players. Journal of Health Promotion Management. 2015; 4(3): 51-59. [Persian]. [Link]

22. Elali ES, Mahdavi A, Jannati Y, Yazdani J, Setareh J. Effect of Benson relaxation response on stress among in hemodialysis patients. Journal of Mazandaran University of Medical Sciences. 2012; 22 (91): 61-68. [Persian]. [Link]

23. Kheiry H, Salehi I, Soltani Shal R. The effectiveness of stress management training on marital satisfaction and parental stress in mothers with children with behavioral problems. Journal of Child Mental Health. 2018; 4(4): 3-13. [Persian]. [Link]

24. Gao L, Curtiss J, Liu X, Hofmann SG. Differential treatment mechanisms in mindfulness meditation and progressive muscle relaxation. Mindfulness. 2018; 9(4): 1268-1279. [Link]

25. Noruzi zamenjani $M$, Masmouei B, Harorani $M$, Ghafarzadegan R, Davodabady F, Zahedi S, et al. The effect of progressive muscle relaxation on cancer patients' self-efficacy. Complement Ther Clin Pract. 2019; 34: 70-75. [Link]

26. Stahl JE, Dossett ML, LaJoie AS, Denninger JW, Mehta DH, Goldman R, et al. Relaxation response and resiliency training and its effect on healthcare resource utilization. PLOS ONE. 2015; 10(10): e0140212. [Link]

27. Luebbert K, Dahme B, Hasenbring M. The effectiveness of relaxation training in reducing treatment-related symptoms and improving emotional adjustment in acute non-surgical cancer treatment: a meta-analytical review. Psychooncology. 2001; 10(6): 490-502. [Link]

28. Rahbar Karbasdehi F, Abolghasemi A, Rahbar Karbasdehi E. Effect of stress management training based on cognitive-behavioral approach on improving parent- child relationship and psychological wellbeing in mothers of children with intellectual disability. Journal of Child Mental Health. 2016; 3(3): 59-71. [Persian]. [Link]

29. Carver ML, O'Malley M. Progressive muscle relaxation to decrease anxiety in clinical simulations. Teaching and Learning in Nursing. 2015;10(2):57-62. [Link]

30. Neacsu V, Sfeatcu IR, Maru N, Dumitrache MA. Relaxation and systematic desensitization in reducing dental anxiety. Procedia Soc Behav Sci. 2014; 127: 474-478. [Link]
31. Janbozorgi M. Effects of progressive relaxation training (prt) on anxiety and skills of control biofeedback responses (EMG and temperature). Research in Medicine. 2005; 29(4): 320-330. [Persian]. [Link]

32. Hamidizade S, Ahmadi F, Asghari M. Study effect of relaxation technique on anxiety and stress in elders with hypertension. Journal of Shahrekord University of Medical Sciences. 2006; 8(2): 45-51. [Persian]. [Link]

33. Soltani N, Safajou F, Amouzeshi Z, Zameni E. The relationship between body image and mental health of students in birjand in 2016 academic year: a short report. Journal of Rafsanjan University of Medical Sciences. 2017; 16(5): 479-486. [Persian]. [Link]

34. Broadbear JT, Jin G, Bierma TJ. Critical thinking dispositions among undergraduate students during their introductory health education course. Health Educ. 2005; 37(1): 8-15. [Link]

35. Taghavi M. Validity and reliability of the general health questionnaire (GHQ-28) in college students of Shiraz University. Journal of Psychology. 2002; 5(4): 381-398. [Persian]. [Link]

36. Najafi M, Solati Dehkordi K, Forouzbakhsh F. Relationship between staff burnout and mental health in staff of nuclear energy organization, Isfahan. Journal of Shahrekord University of Medical Sciences. 2000; 2(2): 34-41. [Persian]. [Link]

37. Segal ZV, Williams JM, Teasdale JD. Mindfulnessbased cognitive therapy for depression-A new approach to preventing relapse. Mohammadkhani P, Tamanaie SH, Jahani O. (Persian translator). Tehran: Tabesh; 2002, pp: 25-55. [Persian].

38. Bernstein DA, Borkovec TD, Hazlett-Stevens H. New directions in progressive relaxation training: a guidebook for helping professionals. Greenwood Publishing Group; 2000. [Link]

39. Robinson KE, Gerhardt CA, Vannatta K, Noll RB. Parent and family factors associated with child adjustment to pediatric cancer. J Pediatr Psychol. 2007; 32(4): 400-410. [Link]

40. Emanuel AS, Updegraff JA, Kalmbach DA, Ciesla JA. The role of mindfulness facets in affective forecasting. Pers Individ Dif. 2010; 49(7): 815-818. [Link]

41. Matourypour P, Ghaedi Heydari F, Bagheri I, Mmarian R. The effect of progressive muscle relaxation on the occupational stress of nurses in critical care units. Jorjani Biomedicine Journal. 2012; 0(1): 9-15. [Persian]. [Link] 